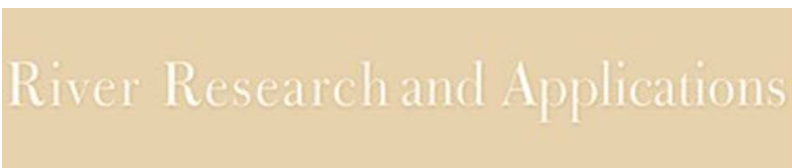

\title{
The effects of replacing native forest on the quantity and impact of in-channel pieces of large wood in Chilean streams
}

\begin{tabular}{|r|l|}
\hline Journal: & River Research and Applications \\
\hline Manuscript ID & RRA-16-0045.R1 \\
\hline Wiley - Manuscript type: & Research Article \\
\hline Complete List of Authors: & $\begin{array}{l}\text { Mao, Luca; Universidad Católica de Chile, Dept. of Ecosystems and } \\
\text { Environment } \\
\text { Ugalde, Fernando; Universidad Católica de Chile, Dept. of Ecosystems and } \\
\text { Environment } \\
\text { Iroume, Andres; Universidad Austral de Chile } \\
\text { Lacy, Shaw; Universidad Católica de Chile, Dept. of Ecosystems and } \\
\text { Environment }\end{array}$ \\
\hline Keywords: & Native forest, pine plantation, large wood, wood jams, fish, Chile \\
\hline
\end{tabular}

\section{SCHOLARONE}

Manuscripts 
1 The effects of replacing native forest on the quantity and impacts of in-channel 2 pieces of large wood in Chilean streams

3

4 Mao L. ${ }^{1 *}$, Ugalde F. ${ }^{1}$, Iroume A. ${ }^{2}$, Lacy S.N. ${ }^{1}$

5

61 Pontificia Universidad Católica de Chile, Department of Ecosystems and 7 Environments, Santiago, Chile

$8{ }^{2}$ Universidad Austral de Chile, Faculty of Forest Sciences and Natural Resources, 9 Valdivia, Chile

* Corresponding author: Luca Mao, Pontificia Universidad Católica de Chile, Department of Ecosystems and Environments, Av. Vicuña Mackenna 4860, Macul, Santiago, Chile, Tel. (56-2) 23545751; E-mail: 1mao@uc.cl

\section{Abstract}

Dead trees in rivers can significantly affect their morphological and ecological properties by increasing flow resistance, affecting sediment transport, and storing organic matter. Logs are usually recruited from banks or along the entire upstream basin. Although it is generally acknowledged that forested headwater streams feature higher volumes of in-channel pieces of large wood, the influence of forest type and forest management of the potential recruitment zone on the volumes and effects of wood have been less explored, especially in relation to the effects of replacing native forests with pine plantations. This paper presents a comparison of volumes of wood, and characteristics and effects on streams draining paired basins with comparable slopes, areas, and hydrologic regimes, but different in terms of land use. The five selected pairs of basins are located in the Coastal and Andean mountain Ranges in central Chile, in order to compare native forest and pine plantation basins. The results show that logs tend to be shorter and with larger diameters in streams draining native forest basins.

29 Because of their smaller dimensions, logs and jams tend to be more mobile and oriented parallel to the flow. Volumes of in-channel wood in native forest basins are only slightly larger than in pine plantation basins, and no differences have been identified in terms of morphological effects on channel geometry. Also, fish type and biomass were comparable among pairs. Evidence highlights the importance of the width of riparian 
buffers in mitigating the effects of land use change, especially the substitution of native forest with plantations.

Keywords: Native forest, pine plantation, large wood, wood jams, fish, Chile

\section{Introduction}

In forested basins, in-channel pieces of large wood (LW, i.e. logs coarser than $0.1 \mathrm{~m}$ and longer than $1 \mathrm{~m}$ ) can significantly affect the morphological and ecological properties of rivers. Logs, especially if jammed, can create steps (Rosenfeld \& Huato, 2003), increase flow resistance (Cadol \& Wohl, 2013), store organic matter (Tank et al., 2010; Beckman \& Wohl, 2014), and increase the connectivity with floodplains (Sear et al., 2010). It has also been demonstrated that in-channel wood increases habitats and biological diversity (Gerhard and Reich, 2000; Cordova et al., 2007; Vera et al., 2014), principally by augmenting morphological diversity and complexity (Gurnell et al., 2002). Indeed, the presence of LW can increases fish number and biomass (e.g. Schenk et al., 2015), and engineered LW is commonly used in river restoration practices in order to increase fish biomass (Abbe et al., 2003). On the other hand, when massively recruited and transported during extreme events, LW is potentially dangerous to human infrastructure (Mazzorana et al., 2009).

Trees can be delivered to the river by natural mortality or after episodic events such as wildfires, windthrow and forest diseases, or localized mass movements on slopes in the form of landslides or debris flows (Hassan et al., 2005). As well, logs can be recruited into river systems from riparian areas through toppling and bank erosion (Jeffries et al., 2003). When recruited, LW can be transported downstream for a distance that depends on the stream power (Merten et al., 2010), the relative size of the logs compared to the stream (Bocchiola et al., 2006; Wohl \& Goode, 2008), and the degree to which logs are already jammed (Gurnell et al., 2002). Log recruitment and transport processes vary spatially and temporally depending on type, magnitude and frequency of processes occurring at the basin scale (Wohl \& Jaeger, 2009). Several attempts have been recently made to organize this into conceptual (e.g. Benda \& Sias, 2003) or numerical models (e.g. Mazzorana et al., 2010; Rigon et al., 2012). Generally, forested headwater streams $\left(<20 \mathrm{~km}^{2}\right)$ feature higher volumes of wood, and logs are less jammed than in downstream reaches. This has been related to the considerable recruitment of logs due 
to high connectivity with colluvial processes occurring on slopes, and with the transport-limited conditions for wood in such environments (Marcus et al., 2002; Abbe \& Montgomery, 2003; Hassan et al., 2005; Wohl \& Jaeger, 2009; Rigon et al., 2012).

The volume of LW in forested basins clearly depends on the type, age, and management of the forest cover. In general, old-growth forests feature a multi-layered canopy with taller and larger diameter trees that supply larger volumes of wood to rivers, which in turn can trap more floated logs, resulting in higher volumes of in-channel wood (Wohl \& Beckman, 2014). Jackson \& Wohl (2015) recently reported higher wood loads in old growth rather than in younger growth forests in the Southern Rocky Mountains (US). However, there is little evidence in the literature on the effects of land use changes on the loads of in-channel wood. For instance, Burrows et al. (2012) showed that streams draining clear-cut eucalyptus basins have greater abundance and volumes of wood than old-growth basins. Nevertheless, there is less field evidence for the effects of native forest replacement with exotic species. There has been extensive study of the effects of substituting native forests with exotic forest plantations on different biota and ecological processes (Lindenmayer et al, 2000; Brockerhoff et al, 2003; Vertessy et al, 2003; Vergara \& Simonetti 2004; Arevalo \& Fernández-Palacios, 2005) by comparing plots established on plantations and adjacent native forests. Evidence show that fish communities can also be affected by pine plantations due to changes in nutrient concentration, shading, amount and quality of organic matter inputs, and that these negative effects can be mitigated by the maintenance of a riparian vegetative boundary (Davies \& Nelson, 1994; Lee et al., 2004). These studies have mainly reported reductions in biodiversity in plantations depending on the management and silvicultural methods. In spite of these studies, much less evidence is available on the impact of native forest substitution by forestry plantations at the basin scale, and especially on how this is reflected at the channel-reach scale. For example, Baillie \& Davies (2002) compared basins with native and pine plantation forest covers in New Zealand and reported higher volumes of LW in pine plantation basins. However, eco-morphological effects appeared to have been greater in the native forest basins. Evidence on this for the Andean region is virtually absent. Pinus radiata D. Don ( $P$. radiata) comprises almost 1.5 of the total 2.7 million hectares of planted forest (INFOR, 2009). Replacement of native forest by pine plantations in Chile has occurred mainly in Andean areas as native forests in coastal areas were largely eliminated before the development of plantations 
101 (Donoso \& Lara, 1995). Final harvest of $P$. radiata plantations in Chile is mainly based 102 on clearcutting, as in most countries where this species is cultivated.

103 The main objective of this study is to assess the impacts of substituting native forests by 104 pine plantations on in-stream large wood and related eco-morphological effects. To 105 achieve that, we compared the characteristics of in-channel LW in streams draining 106 paired basins that are different in terms of land use. The paired-basin study involved the 107 use of five pairs of basins where the pairs were similar in terms of slope, aspect, soils, 108 drainage area, climate, hydrologic regime, and located as close as possible to each other. 109 Five pairs of basins were selected in this study to maximize the difference in terms of 110 land use (native forest $v s$. pine plantation). This paper focuses on the impact of 111 vegetation changes at the basin scale on the amount, size, and effects of in-channel 112 wood in the Andean and Coastal Ranges of Chile.

113

\section{Materials and methods}

115

116

117

118

\subsection{Field sites}

The study was carried out on 5 pairs of basins, with draining areas ranging from approximately 2 to $20 \mathrm{~km}^{2}$ (Table 1), located on the Andean and Coastal Ranges (3 and 2 pairs, respectively), with latitudes ranging from $35^{\circ} 32^{\prime}$ to $37^{\circ} 34^{\prime}$ (Figure 1). The drainage area, stream order, and main slope of the studied basins were determined with a digital elevation model (30 $\mathrm{m}$ size cells) using GIS software. The percentage of forest cover was derived from visual interpretation of recent aerial photos. Although most of the basins with native forest featured nearly the whole area covered with this forest type, nearby basins with plantation that could be selected in this study have areas covered by pine of about $60-75 \%$. Basins with pure pipe plantations are rare in the area, especially because riparian areas are protected by law.

According to Gajardo (1994), all the studied sites are classified in the deciduous forest region, a temperate forest area dominated by deciduous species such as Nothofagus obliqua, N. glauca, N. alpina, and evergreen species like N. dombeyi, Cryptocarya alba, Aextoxicon punctatum, among others. All the watersheds with replacement, previous to planting $P$. radiata on the slopes, were covered with native vegetation, so that any changes registered in the watersheds are attributable to the replacement of native forests by plantations of pine trees and the activities associated with their management. At the time of the surveys, the plantations were between 12 and 18 years old and all had 
135 experienced only one rotation, or clear-cut and replanting. In all cases, the method of 136 harvest is clear-cutting. Tress in the pine plantation areas have mean height of approx. $13720 \mathrm{~m}$ and mean diameter of $25 \mathrm{~cm}$. Although the height of trees is not available for all 138 study sites, the mean diameter of trees in the riparian area and the slopes along the study 139

\begin{abstract}
reaches is reported on Table 2.
\end{abstract}
According to Gutierrez \& Becerra (submitted) the most common native species present on the riparian areas of the 10 basins were A. punctatum, Aristotelia chilensis, Citronella mucronata, Cryptocarya alba, Lomatia dentata, Luma apiculata, Chusquea quila, Boquila trifoliolata, Cissus striata, Hydrangea serratifolia, Lapageria rosea and Lardizabala biternata. The most common exotic species were Rubus ulmifolius, Rosa moschata, Prunella vulgaris and Rumex acetosella.

Although the median size of trees is comparable on riparian forest along the streams draining basins with native forest and pine plantation, riparian forests in pine plantation basins feature lower density of trees, lower diversity of tree species, lower regeneration of tree species, and higher richness of exotic species than in watersheds without replacement of native forest (Gutierrez \& Becerra, submitted).

The northernmost pair on the Coastal Range is located at the estuary of the River Itata (IT). The two basins are approximately $5 \mathrm{~km}^{2}$, and are only $5 \mathrm{~km}$ apart. The basin with native forest (IT-NF) features a deciduous Mediterranean coastal forest but $38 \%$ of the basin area is covered by almost mature Pinus radiata. In the paired basin (IT-PP), the forest cover is dominated by pine plantation (75\%), and a fourth of this area was bare due to a clear-cut that took place two years before the surveys. There is still native forest in $25 \%$ of the basin, especially in the lower part and along the river network, which is quite developed, considering that the stream is an order 4 , despite the small size of the basin $\left(5 \mathrm{~km}^{2}\right)$.

The second pair of basins on the Coastal Range is located in the Trongol Valley (TR). The native forest in this area (TR-NF) is completely covered by mixed deciduous coastal forest. Although there were no visible scars of landslides or debris flows in recent aerial and satellite images, field evidence (e.g. typical depositional levees, and the presence of large boulders) suggests that debris flows have occurred in the past in the main channel. The pair basin (TR-PP) is located $4 \mathrm{~km}$ apart from TR-NF, and $60 \%$ of its area is covered by mature pine plantation.

On the Andean Range, the southernmost pair of basins is located in the Rio Cato Valley, a tributary of the Nuble River (NI). Some $71 \%$ of the surface area of the plantation pair 
169 (NI-PP) is covered with pine plantation, 10\% of which was clear-cut at the time of the 170 surveys, mostly in its uppermost part.

171 A further pair on the Andean Range is located in the Achibueno Valley (PE). The basins 172 are around $3 \mathrm{~km}^{2}$, are at similar altitudes, and are less than $5 \mathrm{~km}$ apart. The native forest 173 in this area (PE-NF) is completely covered by Andean Mediterranean deciduous forest. 174 Its pine plantation counterpart (PE-PP) is planted with $P$. radiata on $66 \%$ of its surface, 175 which had been clear-cut for the first time just a year before this study.

176 The basins of the last pair on the Andean Range the basins are approximately $30 \mathrm{~km}$ 177 apart, and the range of elevations differs more than in the other pairs. Around $67 \%$ of 178 the native forest basin (AN-NF) is covered by the Andean Mediterranean deciduous 179 forest up to $1200 \mathrm{~m}$ a.s.l., above which the basin is almost bare. Pine plantations cover $18068 \%$ of the pair basin (AN-PP), and native forest is concentrated on the highest part of 181 182

\subsection{Field data collection}

A segment of at least $370 \mathrm{~m}$ of every studied basin was surveyed between November 2013 and February 2015 (see Table 2). Between 6 and 12 reaches were selected at every basin. The reaches were defined as uniform in terms of slope, channel width, channel morphology and abundance of in-channel wood. The lengths of the reaches were generally approximately 10 times the bankfull width (Table 2). Longitudinal profiles and three cross-sections per reach were surveyed using a laser distance meter with clinometer and a prisma pole. The cross-sections were measured in order to calculate the average bankfull width and depth, and the average fluvial corridor width of all the reaches. The longitudinal profiles were used to count the number of steps and pools and to calculate the longitudinal area of pools.

Pieces of wood lying both in the active channel and the adjacent active floodplain were measured if the diameter was greater than $10 \mathrm{~cm}$ and the length was greater than $1 \mathrm{~m}$, as previously done in similar field studies (e.g. Comiti et al., 2008; Mao et al., 2008; Iroume et al., 2010; Wohl et al., 2010). Logs lying alone on the bed were classified as single logs, whereas if two logs were grouped or in contact, they were classified as jammed. All single logs and logs belonging to jams were measured. The length and mid-diameter of every log were measured with a tape and a tree caliper, respectively. The volume of each log was calculated from its mid-diameter and length, assuming a 
202 solid cylindrical shape. The size and volume of rootwads present were measured and the 203 volume was added to the volume of the log.

204 Several other measurements were recorded for each piece of wood during the field 205 survey, including the type of piece (log, rootwad, log with rootwads), tree species 206 (broadleafs vs. conifers), orientation to flow (parallel, orthogonal, oblique), state of decay (fresh, semi-decayed or old log), and position (within or outside the bankfull 209 line). The most probable recruitment mechanism that delivered the log into the channel was determined in the field as landslide, debris flow, bank erosion, natural mortality, 210 artificial cutting, or transported from upstream.

211 Jams were defined following a simplification of the Abbe \& Montgomery (2003) 212 classification, which distinguishes autochthonous jams (i.e. key wood elements not 213 fluvially transported from upstream), allochthonous jams (i.e. key elements previously 214 transported from upstream) and combination jams (autochthonous key elements with 215 racked transported pieces). For transversal logs and jams forming a step in the profile, 216 the volume of the downstream pool and the volume of sediment stored upstream were estimated as a solid wedge by measuring their length, width, and depth using a tap measure.

219 At all the studied sites fish was sampled in the summer along a 100m-long reach 220 blocked with nets at the up- and down-stream ends, using a standard double-pass 221 electrofishing technique (HT-2000 Battery Backpack Electrofisher device, Halltech 222 Aquatic Research Inc.). All fish were identified at the species level, measured for total length, and weighed before being returned to the river.

224

225

\section{Results}

226

227

228

229

230

231

232

233

\subsection{Dimensions and type of log pieces in the studied rivers}

The average diameters of in-channel logs ranged from 10 to $25 \mathrm{~cm}$, while the maximum diameters range from 15 to $80 \mathrm{~cm}$ (Figure 2). Taking average diameter into consideration for comparing native forest- and pine plantation-dominated basins, a Ftest confirms that the average diameter was significantly greater in native forest basins in the AN and NI pairs, while the maximum diameter was significantly coarser in the native forest basins of the TR, AN, and NI pairs (Figure 2, Table 3). In-channel logs were generally longer in basins where pine plantations predominate. 
236 from 2 to $4 \mathrm{~m}$, and the average length of logs in basins with pine plantation was greater 237 than those from natural forest basins (statistically significant differences in pairs IT and 238 TR, Table 3). If we take into consideration the longer logs surveyed at the studied 239 reaches, pine plantations basins had significantly longer logs only in the pairs IT and PE 240 (Figure 2, Table 3). However, in all but one case, the longest logs per reach (generally 241 between 5 and $20 \mathrm{~m}$ long) were always pine species, and the longest log surveyed was a 242 pine species of over $30 \mathrm{~m}$ in the PE-PP channel.

243 With the exception of AN, the percentage of pine logs was higher in basins with pine 244 plantation (Figure 3; Table 3). This is especially true for the IT pair, where in the pine 245 plantation basin more than $80 \%$ of the in-channel logs were conifers (more rounded and 246 straight than native species, and with smaller branches). Figure 3 also shows that logs in 247 native forest basins were in a poorer state of conservation in three of the five study pairs 248 (AN, PE, and NI).

249

250

\subsection{Volumes, abundance, and degree of accumulation of logs in the studied rivers}

251 Figure 4 shows the volume of large wood surveyed in the studied sites. To compare

252 reaches of different lengths and widths, volumes are expressed in terms of channel area 253 units (length and bankfull width of the reach). The volumes of wood at the studied 254 reaches varied by a magnitude of two orders, ranging from $6 \mathrm{~m}^{3} \mathrm{ha}^{-1}$ in a reach of the IT 255 native forest basin to $1780 \mathrm{~m}^{3} \mathrm{ha}^{-1}$ in a reach of the TR native forest basin. The volume 256 of logs does not appear to depend on the location of the basins (Coastal vs. Andean 257 Range), but in three of the five pairs (TR, PE and NI) LW volumes in streams draining 258 native basins were nearly double that in the pine plantation basins (Table 3). However, 259 LW volumes were significantly higher in the pine plantation basin of the IT pair (Table $2603)$.

261 Volumes of wood in the studied sites can be compared to other evidence gathered in 262 Chilean streams over the last decade. In particular, data on volumes of in-channel wood 263 are available for five other basins comparable to the studied sites: Tres Arroyos $\left(9 \mathrm{~km}^{2}\right.$, $26464 \%$ with native forest; see Andreoli et al. 2007 and Comiti et al., 2008), El Toro (17.5 $265 \mathrm{~km}^{2} ; 100 \%$ with native forest, see Andreoli et al., 2007), Vueltas de Zorra (in the 266 Coastal Range, $5.87 \mathrm{~km}^{2}, 75 \%$ with native forest; see Iroumé et al., 2011 and Ulloa et 267 al., 2011), Pichun (a pine plantation basin of $4.3 \mathrm{~km}^{2}$ in the Coastal Range; see Iroumé 268 et al., 2011 and Ulloa et al., 2011), and Milico basin, (in the Andean Range, $1.5 \mathrm{~km}^{2}$, $26940 \%$ with native forest, being the rest above the timberline; Gomez, 2013). Figure 5 
270 shows that in small mountain basins $\left(<15 \mathrm{~km}^{2}\right)$ in-channel volumes of large wood can 271 vary by three orders of magnitude, ranging from 10 to $1000 \mathrm{~m}^{3} \mathrm{ha}^{-1}$, with a weak 272 tendency toward a reduction of large wood storage with greater basin area $(R=-0.12 ; p$ $273>0.66)$. Basins with dominant forest cover tend to feature higher volumes of LW (F test $274=1.855 ; \mathrm{p}=0.19)$. However, basins with a higher percentage of native forest do not necessarily have higher volumes of LW, as volumes can vary quite dramatically (two orders of magnitude) even in basins with pure pine plantation.

277 There were no significant differences in single log volumes between the native forest and pine plantation forest pairs at any of the five sites (Figure 4, Table 3). As well, no significant differences between native and pine plantation basins were found in terms of volumes of jammed logs, and significantly higher volumes of jammed LW were only found in the NI native forest.

Because LW volumes depend on both the number and dimension of logs, it is worth considering the number of logs and jams. Figure 6 shows that there were no significant differences between native forest and pine plantation basins in terms of the number of isolated logs, except for the TR basin (Table 3). The only site with a significant difference in the number of log jams was $\mathrm{AN}$, where the number of log jams was higher in the plantation forest site.

288 Figure 7 shows the percentage of logs recruited from the banks/slopes or from upstream reaches (i.e. floated by previous flood events). It appears that in the IT, TR, and NI pairs, a higher percentage of the logs were most likely to have been transported in streams draining native forest basins than from the plantation forest basins. Figure 7 also shows that in four of the five pairs, logs in native forest basins tend to be more parallel than those in pine plantation basins (statically significant differences were found for the IT and AN pairs; Table 3).

295

Figure 8 shows that jams tended to be more autochthonous in pine plantation basins in the AN, NI, and TR pairs, but this difference was statistically significant only for NI. As

297 to the orientation of jams, Figure 8 shows that logs tended to accumulate in a direction 298 parallel to the flow in native forest basins of the TR, AN, and PE pairs (the difference is statistically significant only for AN; Table 3).

300

301

\subsection{Eco-morphological effects of in-channel logs}

302 In the studied sites, no clear evidence of differences were observed between streams 303 draining native forests or pine plantations in terms of the number or dimensions of steps 
304 and pools. Retention of sediments due to jams was not significantly different in native 305 forest vs. pine plantation basins. Indeed, Figure 9 shows that the ratio between the 306 volume of trapped sediments and the volume of jammed logs is between 1 and 3, with 307 no significant differences among basins, except for TR. The remarkable value (around 308 7) obtained for the native forest basin of the TR pair is due to the massive amount of 309 sediments coming from debris flows and trapped by jams.

310 A total of three fish species were encountered in all ten watersheds, namely rainbow 311 trout (Oncorhynchus mykiss), brown trout (Salmo trutta), and the Chilean catfish 312 (Nematogenys inermis). Two of the three species were encountered in all watersheds, 313 except for Las Arañas (TR-NF), where no fish were found. Rainbow trout (O. mykiss) 314 were found in all sites except TR-NF, brown trout (S. trutta) were encountered in six 315 sites (IT-NF, NI-NF, NI-PP, PE-NF, PE-PP, and TR-PP), and Chilean catfish ( $N$. 316 inermis) were found in two sites (AN-PP and IT-PP). If the fish biomass per unit effort 317 (BPUE: $\mathrm{g} 250 \mathrm{~m}^{-2}$ ) is considered, a total of $1250.7 \mathrm{~g}$ of fish per $250 \mathrm{~m}^{-2}$ of stream were 318 found in native forest streams, whereas $1088.8 \mathrm{~g}$ of fish per $250 \mathrm{~m}^{-2}$ of stream were 319 found in pine plantation streams (Figure 10). The difference in biomass (161.9) is not 320 significant (two-sample t-test $=0.42 ; \mathrm{p}=0.69$ ) between the two land uses. In assessing 321 the associations between fish BPUE and LW volumes, sites TR-NF and NI-PP were 322 both excluded as outliers. The volume of large in-channel LW did not correlate 323 significantly with the number of species or BPUE in any of the watersheds, regardless 324 of dominant land use. Only two factors appear to be significantly related to fish BPUE, 325 namely maximum $\log$ diameter $\left(\mathrm{F}=7.57, \mathrm{P}=0.03, \mathrm{R}^{2}=0.58\right)$ and maximum log length $326\left(\mathrm{~F}=3.75, \mathrm{P}=0.10, \mathrm{R}^{2}=0.42\right)$ (Figure 10).

327

328

329

330

\section{Discussion}

\subsection{Dimensions and type of log pieces in native forest vs. pine plantation basins}

The results of the comparative analysis of paired native forest $v s$. pine plantation basins suggest that pieces of large in-channel wood tend to have larger diameters in the native forest basins. This can be related to the fact that native forest basins naturally tend to feature older and coarser plants that are unlikely to be left growing in basins with pine plantations. Indeed, in four of the pairs the mean diameter of standing trees on the slopes is larger in the native forest than in the pine plantation basins. Even if the riparian area is left untouched, it is generally less likely to include very old and large plants in 
338 close proximity to the channel (due to higher frequency of flood disturbances) rather 339 than on the slopes. In fact, in four of the pairs the mean diameter of trees growing in the 340 riparian area is larger in the native forest than in the pine plantation basins On the other hand, in-channel logs tend to be longer in basins with pine plantation. This is probably due to the fact that many pine logs are recruited from the slopes or after clearcutting (many pine logs were artificially cut), and were therefore generally longer than native species, and in a better state of conservation. There was generally a higher percentage of in-channel $\operatorname{logs}$ in a poor state of conservation in native forest basins (i.e. without branches and bark, and with porous/rotted wood), which makes it easier for the flow to break up longer logs during floods. In support of this observation, field evidence suggest that at least in three of the five pairs, logs are predominantly transported from upstream reaches in native forest basins, whereas in pine plantation basins logs were recruited more from banks and slopes than transported from upstream. There is no clear explanation as to why the $\mathrm{AN}$ and PE pairs feature more floated logs in the pine plantation basins, but at least for the AN pair this could be due to the generally smaller dimensions of logs in the pine plantation basin.

Overall, there are weak indications that logs tend to be more parallel to the flow (i.e. while logs in pine plantation basins tend to be more oblique or perpendicular to the flow, indicating that they have been in the channel for less time and are close to the point of recruitment from the banks or slopes. However, the results obtained in our field investigation do not provide unequivocal evidence that there were more transport or combination jams in native forest basins, and that log jams were not predominantly oriented parallel to the flow in native forest basins, as one might expect if logs were relatively smaller and more mobile in native forest basins. Beside, the presence of complex branches in broadleaf species of native forest basins could reduce the mobility of logs if compared with conifers (Dixon and Sear, 2014).

Results show that there were no significant differences between native forest and pine plantation basins in terms of volumes of jammed logs or the number of log jams. The number of log jams per ha of stream ranged from o to more than 200, and significant differences could be identified among pairs. In AN, the very low number of jams in the native forest basins could be caused by the higher discharges (due to the larger basin area) and more likely by the wider bankfull, which reduces the chances of large logs being trapped by the banks and creating jams (as logs tend to be more mobile at 
372 smaller piece length/channel width ratios, e.g. Bocchiola et al., 2006; Dixon \& Sear, 373 2014). The considerably higher number of jams in both TR pair basins (around 100 $374 \mathrm{jams} / \mathrm{ha}$; i.e. around $80 \mathrm{jams} / \mathrm{km}$ ) helps explain the high LW volumes in both, even 375 though log diameter and length were comparable to those in the other studied pairs. This 376 high longitudinal frequency of jams is due to high recruitment of logs and to the 377 presence of potential "trapping" sites. Montgomery et al. (2003), the number of logs per 378 unit of channel length decreases with increasing basin area, and has been reported to be 379 as high as $400 \mathrm{jams} / \mathrm{km}$. The very high number and volumes of LW elements could be 380 related to the fact that the two TR basins are the smallest among the selected pairs. 381 Following the conceptual model of longitudinal distribution of wood proposed by Wohl 382 \& Jaeger (2009), higher LW volumes are likely to be found in narrower and steeper 383 streams, and LW volumes tend to decrease downstream. Wohl \& Jaeger's (2009) model 384 also suggests that the percentage of jammed wood increases with drainage area and 385 channel width due to the higher capacity of $\operatorname{logs}$ to be transported. The fact that the TR 386 pair featured the highest number of jams may thus be related to an unlimited transport 387 capacity condition due to extreme events such as debris flows that transport large 388 amounts of sediments and logs. This seems especially true for the native forest TR 389 basin, where some reaches were depleted of logs while others had large debris jams 390 (sensu Abbe \& Montgomery, 2003). As expected, the percentage of floated logs reached $39180 \%$ of the total number of logs in the native basin of the TR pair, which is affected by 392 debris flows.

393

\subsection{Volumes of logs in native forest vs. pine plantation basins}

395 Results from the studied basins showed that LW volumes varied considerably among 396 basins and sites and by more than two orders of magnitude among reaches (from 1.8 to $397639 \mathrm{~m}^{3} /$ ha in two reaches of the IT PP basin). Indeed, as previously demonstrated, the 398 volume of logs in a river can vary dramatically among reaches depending on the local 399 slope and width (e.g. Wohl \& Jaeger, 2009) or the location of log recruitment points 400 (e.g. Comiti et al., 2006). However, if volumes are averaged among reaches, evidence 401 from the field indicates that native forest basins had larger volumes than pine plantation 402 basins. This is true for at least three of the five pairs of basins (NI, PE, TR). Exploring 403 the reasons this did not hold in the other two pairs (AN and IT) could shed light on the 404 processes involved in determining these differences in volumes. 
The AN basin covered with native forest is the highest, largest and steepest of the studied sites, and almost half of it is above the timberline. Here the LW volume was small, probably due to frequent high magnitude floods, and especially to the lower log length to channel width ratio. The AN pine plantation basin featured a wider riparian area along the studied reaches (more than $60 \mathrm{~m}$ ), and this seemed wide enough to isolate the channel from the processes and land use changes occurring at the basin scale. In fact, even if the pine plantation was close to the studied reach (less than $20 \mathrm{~m}$ from the riparian buffer and less than $40 \mathrm{~m}$ from the upper part of the studied reach), no conifers or chainsaw-cut pieces were found in the AN pine plantation basin.

414 As in the AN pair, the native forest covered basin of the IT pair feature less in-channel 415 wood. In this case, the pine plantation is also very close to the studied reach, but more 416 importantly the riparian buffer along the reach is as narrow as $20 \mathrm{~m}$ (one of the narrowest among the studied sites), and the clear-cutting of the pine plantation occurred mostly in 2013, thus dramatically increasing recruitment from the slopes. This is corroborated by the observation that nearly $90 \%$ of in-channel logs were pine and most of them appeared cut by chainsaw. A further indication that the proximity and connectivity of pine plantation patches to the main channel is important in determining the presence of in-channel pine logs is provided by the native forest basin of the TR 423 pair, where the percentage of pine plantation is very low (i.e. only $1 \%$ of the basin area), 424 but conifers represent almost $18 \%$ of the in-channel logs as the patch of pine plantation 425 is close to the studied reach (around $25 \mathrm{~m}$ ).

426 Results show that volumes of large wood in the mountain basins of the Andean and 427 Coastal ranges of Chile tend to be smaller on streams draining larger basins. Higher volumes of large wood in headwater streams have been related in literature with the fact that logs are only occasionally transported as they have high length to channel width and diameter to water depth ratios, limiting their mobility (e.g. Baillie et al., 2008; Wohl $431 \&$ Jaeger, 2009). Volumes of large wood in small forested basins of Chile range from 10 432 to $1000 \mathrm{~m}^{3} \mathrm{ha}^{-1}$, with an average value or around $100 \mathrm{~m}^{3} \mathrm{ha}^{-1}$ for basins of $5 \mathrm{~km}^{2}$, being 433 the Tres Arroyos an outlayer with more than $1000 \mathrm{~m}^{3} \mathrm{ha}^{-1}$ (Andreoli et al., 2007). This 434 range of volumes is lower than values reported for the Pacific Northwest (Nakamura \& 435 Swanson, 1993; Czarnomski et al., 2008) or Colorado (Jackson \& Wohl, 2015), but are 436 similar to other unmanaged mature hardwood forests (e.g. Gurnell, 2003), and higher 437 than managed basins in the Europe, which feature volumes $<100 \mathrm{~m}^{3} \mathrm{ha}^{-1}$ (e.g. Comiti et 438 al., 2006, Diez et al., 2001). 
4.3 Eco-morphological effects of in-channel logs in native forest vs. pine plantation basins

Regarding the morphological effects of wood, no clear evidence has been found of significant differences between native forest and pine plantation basins, either in terms of pool formation or sediment retention. There are only a few examples in the literature of direct comparison of large pieces of in-channel wood in basins with different land uses, the most interesting being a study comparing large wood volumes and morphological effects on native forest and pine plantation streams in the Nelson Region of New Zealand (Baillie \& Davies, 2002). Baillie \& Davies (2002) found that logs were relatively shorter and had a more parallel orientation to the flow in native forest basins, due to the fact that pieces has more time to break down and be transported fluvially. They found higher volumes of LW in pine plantation basins, but logs in native forest exerted significantly more morphological effects, especially creating more numerous and deeper pools. This is related to the fact that $P$. radiata wood is generally more degradable than that of Nothofagus species. However, the morphological effects of inchannel logs do not necessarily depend only on the large wood volume, as the slope and width of the channel and the size of sediments are also important. For example, Scott et al. (2014) recently showed that the height of log steps strongly depends on the size of sediments in the channel, demonstrating that logs in second-growth basins can form log steps high enough to exert morphological influences on the channel comparable to old growth forest basins if coarse sediments are available in the channel. Jackson \& Wohl (2015) also showed that that streams draining old-growth forests feature higher volumes of in-channel wood and more and larger jams. Even if un our study we could not compare unmanaged $v s$. managed forests of the same type native trees are not used for artificial plantations for commercial use in Chile, the main findings of the present study are also corroborated by the study of Benda \& Bigelow (2014) of different practices of 466 forest management in small mountain basins of northern California. They showed that 467 forest management influences stream wood dynamics, logs being smaller and less 468 abundant in managed forests. Because in our study the native forest were always 469 unmanaged, in

470 In terms of the fish populations in the studied basins, there appears to be little difference 471 between dominant land use and fish biomass in the studied Chilean headwater systems. 472 The total number of species in any given sampled headwater was necessarily low, due 
473 to relatively limited available habitat, the relatively low level of diversity in Chilean 474 rivers (e.g. Dyer, 2000; Habit et al., 2006), and the invasive role that trout play in 475 Chilean streams (Habit et al., 2010).

476 Because the pairs of basins lied at approximately the same elevations and have 477 comparable slope, size, and order, the dominant physical conditions affecting fish 478 species presences are likely to be very similar. As well, riparian vegetation along the 479 streams is at least $20 \mathrm{~m}$ wide, providing heavy shading to the watercourses, meaning 480 that the waterways experienced very little heat gain in both pine plantation and native 481 forest basins, providing both with low and stable water temperatures. Thus, although 482 differences in forest cover at the basin scale are likely to change the allochthonous 483 energy sources between native forests and pine plantations, this is not reflected in 484 statistically significant differences in the amount of fish biomass, number and diversity 485 of fish between native and pine plantation basins within the studied sites.

486

\subsection{Management implications}

488 Among other authors, Whiles \& Wallace (1997) have shown that converting native 489 forest to an exotic monoculture can influence benthic taxonomic composition. For 490 instance, in low-order streams in central Chile, Mancilla et al. (2009) found significantly higher diversity of macroinvertebrates in channels draining basins with native vegetation than in basins with exotic species. Similarly, studying mountain streams of Argentinian Patagonia, Miserendino \& Masi (2010) found that shredders were more abundant in native forest rather than in pine plantation basins, and Valdovinos (2001) found more shredders in native forest than in P. radiata basins in Chilean streams. Martinez et al. (2013) found lower densities of shredders in streams of the Cordillera Cantábrica (Spain) where native vegetation had been replaced by pine plantation. However, all these studies stress the importance of riparian vegetation along the river network, which can buffer the effects of land use changes at the basin scale, especially by providing coarse particulate organic matter to the streams, including large

502 Studying wood recruitment and transport processes in small forested mountain basins of 503 California, Benda \& Bigelow (2014) found that most wood recruitment occurs in a 504 buffer narrower than $50 \mathrm{~m}$ along channels, and that landslides can extend the main 505 source distance. Jensen et al. (2014) also showed that the volume of wood in small 506 streams $\left(<30 \mathrm{~km}^{2}\right)$ of the Upper Little Tennessee River strongly depends on the type 
507 and dimension of trees in the riparian area. They further suggested that the 10 -m-wide 508 buffer around reaches is the most important source of wood recruitment. Other authors 509 (Diez et al., 2001; Roth et al., 1996) have recommended wider buffers (20 to $30 \mathrm{~m}$ ) in 510 order to allow abundant recruitment of large and coarse logs to rivers.

511 Current Chilean legislation recognizes the importance of protecting riparian areas in 512 order to preserve the multiple ecosystem services they provide. Romero et al. (2014) 513 noted that references to the protection of riparian vegetation in Chilean legislation date 514 back to 1931 (e.g. Pellet et al. 2005). However, legislation on this topic is now 515 abundant, but fragmented, and lacking coherence (Romero et al., 2014). Current riparian 516 conservation regulations for plantations of Eucalyptus spp. and Pinus radiata D. Don 517 require a buffer of $25 \mathrm{~m}$ on both sides of the channel. The width of this protected area 518 for rivers in forested areas is 30 and $15 \mathrm{~m}$ on both sides for permanent and intermittent 519 rivers, respectively (Gayoso \& Gayoso, 2003; Pellet et al. 2005). This buffer extends to $520200 \mathrm{~m}$ for steep basins with risks of slope instabilities. Still, it is possible to better 521 define these buffers and to specify standards for restoring riparian areas (Romero et al., 522 2014). As well, there is no legislation regulating the removal of logs from channels. 523 Evidence suggests that maintaining a wide riparian forest is crucial for maintaining 524 positive ecological functions of channels and for allowing abundant recruitment of large 525 woody elements of native species that can exert strong geomorphic influence on 526 channels. Accordingly, snag removal should be discouraged, especially from small 527 streams that supply wood to downstream reaches, and where transport of potentially 528 risky large elements is less likely due to the high ratios between log diameter and water 529 depth and between log length and channel width (see Gurnell et al., 2002; Ulloa et al., 530 2011). Indeed, as reported by Mao et al (2013), log removal and riparian vegetation 531 clear cuts are not effective strategies for reducing hazards since high-magnitude events 532 are able to recruit trees from hillslopes due to mass wasting processes (Lucía et al., 533 2015). A valuable alternative is wood retention measures such as rope net barriers and 534 filter dams (e.g. Mao et al., 2013) to protect sensitive local infrastructure.

\section{Final remarks}

537

538 This paper presents novel evidence gathered from field surveys in five pairs of basins in 539 Chile on how land use changes, and in particular the substitution of native forest by pine 540 plantation, can affect the volume and degree of organization of large wood in the 
1

2

3

4

5

6

7

8

9

10

541 streams draining these basins. The results show that in streams draining native forest

542 basins, logs tend to be coarser and shorter, and tend to be oriented parallel to the flow as

543 they are more easily transported. Volumes of in-channel wood tend to be higher in 544 native forest basins. However, although streams in native forest basins tend to feature 545 more jams, no significant differences were detected in terms of the number or 546 dimension of pools, or volumes of trapped sediments. As well, fish species and biomass 547 were not significantly different from those in streams draining pine plantation basins.

\section{Acknowledgments}

549

550 We thank Joaquin Lobato, Claudio Gomez, Ernesto Cobo, and Jose Donoso for helping 551 in the field. We also thank Victoria Madrid for helping assess watershed-based variables 552 through GIS. This research was undertaken under the project USA2012-0011 "Effect of 553 native forest replacement by pine plantations on biodiversity and ecosystem processes 554 of Andean riparian and riverine habitats in the south of Chile" funded by Conicyt. We 555 thank Forestal Arauco and private landowners for their support and for allowing access 556 to their properties. 


\section{References}

Abbe TB, Montgomery DR. 2003. Patterns and processes of wood debris accumulation in the Queets river basin, Washington. Geomorphology 51, 81-107.

Abbe T, Pess G, Montgomery DR, Fetherston KL. 2003. 17. Integrating Engineered Log Jam Technology into River Rehabilitation. Restoration of Puget Sound Rivers, 443.

Andreoli A, Comiti F, Lenzi MA. 2007. Characteristic, distribution and geomorphic role of large woody debris in a mountain stream of the Chilean Andes. Earth Surface Processes and Landforms 32, 1675-1692.

Arevalo JR, Fernández-Palacios JM. 2005. Gradient analysis of exotic Pinus radiata plantations and potential restoration of natural vegetation in Tenerife, Canary Islands (Spain). Acta Oecologica 27, 1-8.

Baillie BR, Davies TR. 2002. Influence of large woody debris on channel morphology in native forest and pine plantation streams in the Nelson region, New Zealand. New Zealand Journal of Marine and Freshwater Research 36, 763-774.

Baillie BR, Garrett LG, Evanson AW. 2008. Spatial distribution and influence of large woody debris in an old-growth forest river system. New Zealand. Forest Ecology and Management 256, 20-27.

Beckman ND, Wohl EE. 2014. Effects of forest stand age on the characteristics of logjams in mountainous forest streams. Earth Surface Processes and Landforms 39, 1421-1431.

Benda L, Bigelow P. 2014. On the patterns and processes of wood in northern California streams. Geomorphology 209, 79-97.

Benda L, Sias J. 2003. A quantitative framework for evaluating the wood budget. Forest Ecology and Management 172, 1-16.

Bocchiola D, Rulli MC, Rosso R. 2006. Flume experiments on wood entrainment in rivers. Advances in Water Resources 29(8), 1182-1195.

Brockerhoff EG, Ecroyd C, Leckie AC, Kimberley MO. 2003. Diversity and succession of adventive and indigenous vascular understory plants in Pinus radiata plantation forests in New Zealand. Forest Ecology and Management 185, 307326.

Burrows RM, Magierowski RH, Fellman JB, Barmuta LA. 2012. Woody debris input and function in old-growth and clear-felled headwater streams. Forest Ecology and Management 286, 73-80.

Cadol D, Wohl E. 2013. Variable contribution of wood to the hydraulic resistance of headwater tropical streams. Water Resources Research 49, 4711-4723.

Czarnomski NM, Dreher DM, Snyder KU, Jones JA, Swanson FJ. 2008. Dynamics of wood in stream networks of the western Cascades Range, Oregon. Canadian Journal of Forest Resources 38: 2236-2248.

Comiti F, Andreoli A, Lenzi MA, Mao L. 2006. Spatial density and characteristics of woody debris in five mountain rivers of the Dolomites (Italian Alps). Geomorphology 78, 44-63.

Comiti F, Andreoli A, Mao L, Lenzi MA. 2008. Wood storage in three mountain streams of the Southern Andes and its hydro-morphological effects. Earth Surface Processes and Landforms 33, 244-262.

Cordova JM, Rosi-Marshall EJ, Yamamuro AM, Lamberti GA. 2007. Quantity, controls, and functions of large woody debris in Midwestern USA streams. River Res. Applic. 23, 21-33. 
Davies PE, Nelson M 1994. Relationships between riparian buffer widths and the effects of logging on stream habitat, invertebrate community composition and fish abundance. Australian Journal of Marine and Freshwater Research 45(7): 1289-1305.

Diez JR, Elosegi A, Pozo J. 2001. Woody debris in North Iberian streams: Influence of geomorphology, vegetation, and management. Environmental Management 28, 687-698.

Dixon SJ, Sear DA. 2014. The influence of geomorphology on large wood dynamics in a low gradient headwater stream. Water Resources Research 50, 9194-9210, doi:10.1002/2012WR013085.

Donoso C, Lara A. 1995. Utilización de los bosques nativos en Chile: pasado, presente y futuro, in: Armesto, J., Villagrán, C., Kalin, M.T. (Eds), Ecología de los bosques nativos de Chile. Editorial Universitaria, Chile, pp. 367-387.

Dyer B. 2000. Systematic review and biogeography of the freshwater fishes of Chile. Estudios Oceanológicos 19, 77-98.

Francis RA. 2007. Size and position matter: riparian plant establishment from fluvially deposited trees. Earth Surface Processes and Landforms 32, 1239-1243.

Gajardo R. 1994. La vegetación natural de Chile. Clasificación y distribución geográfica. Santiago (Chile): Editorial Universitaria. p. 163.

Gayoso J, Gayoso S. 2003. Diseño de zonas ribereñas: Requerimientos de un ancho mínimo. Valdivia, Chile. Universidad Austral de Chile. Facultad de Ciencias Forestales. $12 \mathrm{p}$.

Gerhard M, Reich M, 2000. Restoration of streams with large wood: Effects of accumulated and built-in wood on channel morphology, habitat diversity and aquatic fauna. Internat. Rev. Hydrobiol. 85, 123-137.

Gomez C. 2013. Material leñoso en arroyos andinos de alta pendiente. Ms.C thesis, Pontificia Universidad Católica de Chile, 43 pp.

Gurnell AM. 2003. Wood storage and mobility. In The ecology and management of wood in world rivers Edited by Gregory SV, Boyer KL, Gurnell AM, American Fisheries Society Symposium 37, Bethesda, Maryland. pp. 75-91.

Gurnell AM, Piegay H, Swanson FJ, Gregory SV. 2002. Large wood and fluvial processes. Freshwater Biology 47, 601-619.

Gutierrez I, Becerra P. Effect of native forest replacement by Pinus radiata plantations on plant communities of riparian vegetation in South - Central Chile. Under review at Plant Ecology and Diversity.

Habit E, Dyer B, Vila I. 2006. Estado de conocimiento de los peces dulceacuícolas de Chile. Gayana 70(1), 100-113.

Habit E, Piedra P, Ruzzante DE, Walde SJ, Belk MC, Cussac VE, Gonzalez J, Colin N. 2010. Changes in the distribution of native fishes in response to introduced species and other anthropogenic effects. Global Ecology and Biogeography 19, 697-710.

Hassan MA, Hogan DL, Bird SA, May CL, Gomi T, Campbell D. 2005. Spatial and temporal dynamics of wood in headwater streams of the Pacific Northwest. J. Am. Water Resour. As. 41, 899-919.

INFOR. 2009. Inventario de bosques plantados por especie según región acumulado a diciembre de 2009. Available at www.infor.cl.

Iroumé A, Andreoli A, Comiti F, Ulloa H, Huber A. 2010. Large wood abundance, distribution and mobilization in a third order Coastal mountain range river system, southern Chile. Forest Ecology and Management 260, 480-490. 
Iroumé A, Mao L, Andreoli A, Ulloa H, Ardiles MP. 2015. Large wood mobility processes in low-order Chilean river channels. Geomorphology 228, 681-693.

Iroumé A, Mao L, Ulloa H, Ruz C, Andreoli A. 2014. Large wood volume and longitudinal distribution in channel segments draining catchments with different land use, Chile. Open Journal of Modern Hydrology 4, 57-66.

Iroumé A, Ulloa H, Lenzi MA, Andreoli A, Gallo C. 2011. In-stream large wood mobility and recruitment in two channels in the Coastal Mountain Range, Chile. Bosque 32(3), 247-254.

Jackson CR, Sturm CA. 2002. Woody debris and channel morphology in first- and second-order forested channels in Washington's Coast Ranges. Water Resources Research 38, 16-14.

Jackson KJ, Wohl EE. 2015. Instream wood loads in montane forest streams of the Colorado Front Range, USA. Geomorphology 234, 161-170.

Lee P, Smyth C, Boutin, S 2004. Quantitative review of riparian buffer width guidelines from Canada and the United States. Journal of Environmental Management 70(2): 165-180.

Jeffries R, Darby SE, Sear DA. 2003. The influence of vegetation and organic debris on flood-plain sediment dynamics: case study of a low-order stream in the New Forest, England. Geomorphology 51, 61-80.

Jensen KC, Leigh DS, Jackson CR. 2014. Scales and arrangements of large wood in first- through fifth-order streams of the Blue Ridge Mountains. Physical Geography 35(6), 532-560.

Lindenmayer DB, McCarthy MA, Parris KM, Pope ML. 2000 Habitat Fragmentation, Landscape Context and Mammalian Assemblages in Southeastern Australia. J. Mammal. 81, 787-797.

Lucía A, Comiti F, Borga M, Cavalli M, Marchi L. 2015. Dynamics of large wood during a flash flood in two mountain catchments. Nat. Hazards Earth Syst. Sci. $15,1741-1755$.

Mancilla G, Valdovinos C, Azocar M, Jorquera P, Figueroa R. 2009. Efecto del reemplazo de la vegetación nativa de ribera sobre la comunidad de macroinvertebrados bentónicos en arroyos de climas templados, Chile central. Hidrobiológica 19(3), 193-203.

Mao L, Andreoli A, Comiti F, Lenzi MA. 2008. Geomorphic effects of large wood jams on a sub-Antarctic mountain stream. River Research and Applications 24(3): 249-266.

Mao L, Andreoli A, Iroumé A, Comiti F, Lenzi MA. 2013. Dynamics and management alternatives of in-channel large wood in mountain basins of the southern Andes. Bosque 34(3): 319-330.

Marcus WA, Marston RA, Colvard CR, Gray RD. 2002. Mapping the spatial and temporal distributions of woody debris in streams of the Greater Yellowstone Ecosystem, USA. Geomorphology 44: 323-335.

Martínez A, Larrañaga A, Pérez J, Descals E, Basaguren A, Pozo J. 2013. Effects of pine plantations on structural and functional attributes of forested streams. Forest Ecology and Management 310: 147-155.

Mazzorana B, Hübl J, Zischg A, Largiader A. 2010. Modelling woody material transport and deposition in alpine rivers. Natural Hazards 56: 425-449.

Mazzorana B, Zischg A, Largiader A, Hubl J. 2009. Hazard index maps for woody material recruitment and transport in alpine catchments. Natural Hazards and Earth System Science 9: 197-209. 
Merten E, Finlay J, Johnson L, Newman R, Stefan H, Vondracek B. 2010. Factors

Miserendino ML, Masi CI. 2010. The effects of land use on environmental features and influencing wood mobilization in streams. Water Resources Research 46: W10514.

functional organization of macroinvertebrate communities in Patagonian low order streams. Ecological Indicators 10: 311-319.

Montgomery DR, Collins BD, Buffington JM, Abbe TB. 2003. Geomorphic effects of wood in rivers. In The ecology and management of wood in world rivers Edited by Gregory SV, Boyer KL, Gurnell AM, American Fisheries Society Symposium 37, Bethesda, Maryland. pp. 21-48.

Nakamura F, Swanson FJ. 1993. Effects of course woody debris on morphology and sediment storage of a mountain stream system in Western Oregon. Earth Surface Processes and Landforms 18: 43-61.

Pellet P, Ugarte E, Osorio E, Herrera F. 2005. Conservación de la biodiversidad en Chile, ¿Legalmente suficiente? La necesidad de cartografiar la ley antes de decidir. Revista Chilena de Historia Natural 78: 125-14.

Rigon E, Comiti F, Lenzi MA. 2012. Large Wood Storage in Streams of the Eastern Italian Alps and the Relevance of Hillslope Processes. Water Resources Research 48: 1-18.

Romero FI, Cozano MA, Gangas RA, Naulin PI. 2014. Zonas ribereñas: protección, restauración y contexto legal en Chile. Bosque 35(1): 3-12.

Rosenfeld JS, Huato L. 2003. Relationship between large woody debris characteristics and pool formation in small coastal British Columbia streams. North American Journal of Fisheries Management 23(3): 928-938.

Roth NE, Allan JD, Erickson DL. 1996. Landscape influences on stream biotic integrity assessed at multiple spatial scales. Landscape Ecology 11: 141-156.

Scott DN, Montgomery DR, Wohl EE. 2014. Log step and clast interactions in mountain streams in the central Cascade Range of Washington State, USA. Geomorphology 216: 180-186.

Sear DA, Millington CE, Kitts DR, Jeffries R. 2010. Logjam controls on channel: floodplain interactions in wooded catchments and their role in the formation of multi-channel patterns. Geomorphology 116: 305-319.

Schenk ER, McCargo JW, Moulin B, Hupp CR, Richter JM. 2015. The Influence of Logjams on Largemouth Bass (Micropterus Salmoides) Concentrations on the Lower Roanoke River, a Large Sand-Bed River. River Research and Applications 31(6), 704-711.

Tank J, Rosi-Marshall E, Griffiths N, Entrekin S, Stephen M. 2010. A review of allochthonous organic matter dynamics and metabolism in streams. Journal of the North American Benthological Society 29(1): 118-146.

Ulloa H, Iroume A, Lenzi MA, Andreoli A, Álvarez C, Barrera V. 2011. Material leñoso de gran tamaño en dos cuencas de la Cordillera de la Costa de Chile con diferente historia de uso del suelo. Bosque 32(3): 235-245.

Valdovinos C. 2001. Procesamiento de detritus ripariano por macroinvertebrados bentonicos en un estero boscoso de Chile central. Revista Chilena de Historia Natural 74: 445-453.

Vera M, Jara C, Iroume A, Ulloa H, Andreoli A, Barrientos S. 2014. Reach scale ecologic influence of in-stream large wood in a Coastal Mountain range channel, Southern Chile. Gayana 78(2): 85-97.

Vergara PM, Simonetti JA. 2004. Avian responses to fragmentation of the Maulino forests in central Chile. Oryx 38: 383-388. 
755 Vertessy RA, Zhang L, Dawes WR. 2003. Plantations, river flows and salinity. 756 Australian Forestry 66: 55-61.

757 Whiles MR, Wallace JB. 1997. Leaf litter decomposition and macroinvertebrate 758 communities in headwater streams draining pine and hardwood catchments. 759 Hydrobiologia 353: 107-119.

760 Wohl EE, Beckman ND. 2014. Controls on the longitudinal distribution of channel761 spanning logjams in the Colorado Front Range, USA. River Research and 762 Applications 30: 112-131.

763 Wohl EE, Cenderelli DA, Dwire KA, Ryan-Burkett SE, Young MK, Fausch KD. 2010. 764 Large in-stream wood studies: a call for common metrics. Earth Surface 765 Processes and Landforms 35: 618-625.

Wohl EE, Goode JR. 2008. Wood dynamics in headwater streams of the Colorado Rocky Mountains. Water Resources Research 44, W09429.

Wohl EE, Jaeger KL. 2009. A conceptual model for the longitudinal distribution of wood in mountain streams. Earth Surface Processes and Landforms 34: 329344. 
1

2

3

4

5

6

7

8

9

10

11

12

13

14

15

16

17

18

19

20

21

22

23

24

25

26

27

28

29

30

31

32

33

34

35

36

37

38

39

40

41

42

43

44

45

46

47

48

49

50

51

52

53

54

55

56

57

58

59

60

\begin{tabular}{|c|c|c|c|c|c|c|c|c|c|c|}
\hline \multirow{2}{*}{$\frac{\text { Pair }}{\text { Stream }}$} & \multicolumn{2}{|c|}{ IT } & \multicolumn{2}{|c|}{ TR } & \multicolumn{2}{|c|}{ AN } & \multicolumn{2}{|c|}{$\mathrm{PE}$} & \multicolumn{2}{|c|}{$\mathrm{NI}$} \\
\hline & $\begin{array}{l}\text { Manqu } \\
\mathrm{i}\end{array}$ & Mela & Arañas & $\begin{array}{l}\text { Cereza } \\
\mathrm{s}\end{array}$ & $\begin{array}{l}\text { Piuque } \\
\text { nes }\end{array}$ & $\begin{array}{l}\text { Potreri } \\
\text { llos }\end{array}$ & $\begin{array}{l}\text { Sin } \\
\text { Puerta }\end{array}$ & $\begin{array}{l}\text { Duend } \\
\mathrm{e}\end{array}$ & Queñes & Cabras \\
\hline \multirow[t]{2}{*}{ Code } & IT-NF & IT-PP & TR-NF & TR-PP & $\begin{array}{l}\mathrm{AN}- \\
\mathrm{NF}\end{array}$ & $\begin{array}{l}\text { AN- } \\
\text { PP }\end{array}$ & PE-NF & PE-PP & NI-NF & NI-PP \\
\hline & $36^{\circ} 23^{\prime}$ & $36^{\circ} 21^{\prime} 4$ & & $37^{\circ} 34^{\prime}$ & $35^{\circ} 49^{\prime}$ & $35^{\circ} 32^{\prime}$ & $36^{\circ} 04^{\prime}$ & $36^{\circ} 03^{\prime}$ & \multirow{4}{*}{\multicolumn{2}{|c|}{$\mid \begin{array}{cc}36^{\circ} 40^{\prime} 21 & 36^{\circ} 41^{\prime} 17 \\
" & " \\
71^{\circ} 34^{\prime} 37 & 71^{\circ} 37^{\prime} 42 \\
" & "\end{array}$}} \\
\hline \multirow{3}{*}{$\begin{array}{l}\text { Coordinates } \\
(\mathrm{S}-\mathrm{W})\end{array}$} & $15^{\prime \prime}$ & $8 "$ & $37^{\circ} 34^{\prime}$ & $56^{\prime \prime}$ & $03 "$ & $20 "$ & $19 "$ & $49^{\prime \prime}$ & & \\
\hline & $72^{\circ} 44^{\prime}$ & $72^{\circ} 46^{\prime} 3$ & $28^{\prime \prime} 73^{\circ}$ & $73^{\circ} 16^{\prime}$ & $71^{\circ} 11^{\prime}$ & $71^{\circ} 11^{\prime}$ & $71^{\circ} 19^{\prime}$ & $71^{\circ} 20^{\prime}$ & & \\
\hline & $20 "$ & $8 "$ & $13^{\prime} 19^{\prime \prime}$ & $53 "$ & $05 "$ & $58 "$ & $16^{\prime \prime}$ & $45^{\prime \prime}$ & & \\
\hline Basin area $\left(\mathrm{km}^{2}\right)$ & 4.92 & 4.83 & 1.43 & 2.54 & 11.86 & 9.13 & 2.35 & 3.53 & 10.21 & 11.22 \\
\hline Max elev. (m a.s.1.) & 571 & 558 & 982 & 730 & 2087 & 865 & 1153 & 1078 & 1551 & 1168 \\
\hline Min elev. (m a.s.1.) & 78 & 75 & 560 & 224 & 660 & 452 & 520 & 530 & 565 & 576 \\
\hline Mean basin slope (\%) & 18.6 & 9.4 & 26.2 & 17.8 & 28.2 & 10.5 & 26.1 & 26.8 & 12.9 & 10.6 \\
\hline Basin orientation & $\mathrm{S}$ & $\mathrm{O}$ & $\mathrm{S}$ & $\mathrm{S}-\mathrm{O}$ & $\mathrm{S}$ & $\mathrm{S}-\mathrm{O}$ & $\mathrm{N}-\mathrm{O}$ & $\mathrm{N}-\mathrm{O}$ & $\mathrm{N}-\mathrm{O}$ & $\mathrm{N}-\mathrm{O}$ \\
\hline Channel order & 4 & 4 & 2 & 2 & 3 & 2 & 2 & 3 & 3 & 3 \\
\hline Hydrologic regime & pluvial & Pluvial & pluvial & pluvial & $\begin{array}{l}\text { Pluvia } \\
1 / \\
\text { nival }\end{array}$ & $\begin{array}{c}\text { Pluvia } \\
1\end{array}$ & $\begin{array}{c}\text { Pluvia } \\
1\end{array}$ & $\begin{array}{c}\text { Pluvia } \\
1\end{array}$ & $\begin{array}{c}\text { Pluvial/ } \\
\text { nival }\end{array}$ & $\begin{array}{c}\text { Pluvial/ } \\
\text { nival }\end{array}$ \\
\hline $\begin{array}{l}\text { Mean annual precip. } \\
(\mathrm{mm})\end{array}$ & & & & & 2 & & & & 14 & 90 \\
\hline Climate & $\begin{array}{r}\text { Ten } \\
\text { Medi }\end{array}$ & $\begin{array}{l}\text { erate } \\
\text { ranean }\end{array}$ & $\begin{array}{r}\text { Tem } \\
\text { Medit } \\
\text { hu }\end{array}$ & $\begin{array}{l}\text { erate } \\
\text { ranean } \\
\text { hid }\end{array}$ & $\begin{array}{r}\text { Tem } \\
\text { Medit } \\
\text { sub- }\end{array}$ & $\begin{array}{l}\text { erate } \\
\text { ranean } \\
\text { amid }\end{array}$ & $\begin{array}{r}\text { Tem } \\
\text { Medit } \\
\text { hu }\end{array}$ & $\begin{array}{l}\text { erate } \\
\text { ranean } \\
\text { hid }\end{array}$ & $\begin{array}{r}\text { Temp } \\
\text { Mediter }\end{array}$ & $\begin{array}{l}\text { erate } \\
\text { rranean }\end{array}$ \\
\hline Dominant forest type & Maule & $\begin{array}{l}\text { eciduous } \\
\text { est }\end{array}$ & $\begin{array}{r}\text { Con } \\
\text { deciduc }\end{array}$ & $\begin{array}{l}\text { pcion } \\
\text { s forest }\end{array}$ & $\begin{array}{r}\text { Dec } \\
\text { mount }\end{array}$ & uous & $\begin{array}{r}\mathrm{M} \\
\text { deciduc }\end{array}$ & $\begin{array}{l}\text { ule } \\
\text { s forest }\end{array}$ & $\begin{array}{r}\text { Decid } \\
\text { mountai }\end{array}$ & $\begin{array}{l}\text { luous } \\
\text { in forest }\end{array}$ \\
\hline$\%$ native forest & 62 & 25 & 99 & 40 & 100 & 32 & 100 & 34 & 98 & 29 \\
\hline$\%$ pine plantation & 38 & 75 & 1 & 60 & 0 & 68 & 0 & 66 & 2 & 71 \\
\hline $\begin{array}{l}\text { Width of the riparian } \\
\text { buffer }(\mathrm{m})\end{array}$ & 57.6 & 22.0 & 50.1 & 34.1 & 53.9 & 66.3 & 29.2 & 22.5 & 82.9 & 40.9 \\
\hline $\begin{array}{l}\text { Distance from the } \\
\text { closest plantation to } \\
\text { the riparian area (m) }\end{array}$ & 46.0 & 11.7 & 26.1 & 11.83 & - & 11.64 & - & 16.1 & 98.6 & 12.1 \\
\hline $\begin{array}{l}\text { Distance from the } \\
\text { closest plantation to } \\
\text { the studied reach }(\mathrm{m})\end{array}$ & 53.8 & 10.9 & 53.2 & 21.8 & - & 37.4 & - & 12.5 & 145.2 & 30.6 \\
\hline
\end{tabular}

Table 1. Main characteristics of the studied basins (NF stands for native forest and PP for pine plantation)

\section{TABLES}


Table 2. Main characteristics of the surveyed channels

781

\begin{tabular}{|c|c|c|c|c|c|c|c|c|c|c|}
\hline Pair & & & & & & & & & $\mathrm{N}$ & \\
\hline Stream & Manqui & Mela & Arañas & Cerezas & $\begin{array}{l}\text { Piuque } \\
\text { nes }\end{array}$ & $\begin{array}{c}\text { Potrerill } \\
\text { os }\end{array}$ & $\begin{array}{c}\text { Sin } \\
\text { Puerta }\end{array}$ & Duende & Queñes & Cabras \\
\hline Code & IT-NF & IT-PP & TR-NF & TR-PP & $\begin{array}{l}\text { AN- } \\
\text { NF }\end{array}$ & AN-PP & PE-NF & PE-PP & NI-NF & NI-PP \\
\hline $\begin{array}{l}\text { Number of } \\
\text { reaches }\end{array}$ & 10 & 9 & 12 & 8 & 6 & 8 & 6 & 6 & 7 & 7 \\
\hline $\begin{array}{l}\text { Length of the } \\
\text { studid segment } \\
\text { (m) }\end{array}$ & 667.8 & 656.6 & 822.4 & 375.4 & 781.7 & 907.9 & 543.3 & 715.3 & 801.4 & 718.8 \\
\hline $\begin{array}{l}\text { Average } \\
\text { channel slope } \\
\left(\mathrm{m} \mathrm{m}^{-1}\right)\end{array}$ & 0.080 & 0.029 & 0.168 & 0.073 & 0.086 & 0.016 & 0.047 & 0.046 & 0.043 & 0.015 \\
\hline $\begin{array}{l}\text { Average } \\
\text { channel } \\
\text { bankfull width } \\
\text { (m) }\end{array}$ & 5.0 & 4.5 & 4.1 & 4.6 & 13.3 & 3.7 & 2.7 & 3.1 & 8.9 & 8.5 \\
\hline $\begin{array}{l}\text { Number of } \\
\text { pools (pools } \\
\left.\mathrm{km}^{-1}\right)\end{array}$ & 102.4 & 112.5 & 149.9 & 127.8 & 64.5 & 55.4 & 174.2 & 125.2 & 86.1 & 51.4 \\
\hline $\begin{array}{l}\text { Dominant } \\
\text { channel } \\
\text { morphology }\end{array}$ & $\begin{array}{l}\text { Cascade } \\
\text { steps- } \\
\text { pools }\end{array}$ & $\begin{array}{c}\text { Riffles- } \\
\text { pools }\end{array}$ & $\begin{array}{l}\text { Riffles- } \\
\text { step- } \\
\text { pools }\end{array}$ & $\begin{array}{c}\text { Riffles- } \\
\text { pools }\end{array}$ & $\begin{array}{l}\text { Steps- } \\
\text { pools }\end{array}$ & $\begin{array}{l}\text { Riffles } \\
\text {-pools }\end{array}$ & $\begin{array}{l}\text { Riffles } \\
\text { steps- } \\
\text { pools }\end{array}$ & $\begin{array}{l}\text { Riffles } \\
\text { steps- } \\
\text { pools }\end{array}$ & $\begin{array}{c}\text { Riffles- } \\
\text { steps-pools }\end{array}$ & $\begin{array}{l}\text { Riffles- } \\
\text { pools }\end{array}$ \\
\hline $\begin{array}{l}\text { MDBH* of } \\
\text { trees in the } \\
\text { riparian area }\end{array}$ & 24.40 & 16.00 & 23.95 & 8.90 & 14.70 & 11.40 & 11.86 & 14.92 & 16.59 & 12.44 \\
\hline $\begin{array}{l}\mathrm{MDBH}^{*} \text { of } \\
\text { trees on the } \\
\text { slopes }\end{array}$ & 31.88 & 25.08 & 20.62 & 15.06 & 17.47 & 22.03 & 9.96 & 3.55 & 16.26 & 19.84 \\
\hline
\end{tabular}

782 *MDBH: Mean Diameter at Breast Height

783

784

785

786

\begin{tabular}{|c|c|c|c|c|c|}
\hline & IT & TR & $\mathrm{AN}$ & $\mathrm{PE}$ & $\mathrm{NI}$ \\
\hline Average log diameter $(\mathrm{m})$ & 1.721 & 0.379 & 0.392 & 1.811 & $\mathbf{2 4 . 4 2 7}$ \\
\hline Maximum log diameter (m) & 0.335 & 2.185 & 0.392 & 0.402 & 50.674 \\
\hline Average log length (m) & 2.397 & 4.438 & 0.001 & 0.039 & 0.046 \\
\hline Maximum log length (m) & 1.746 & 0.943 & 0.636 & 3.138 & 0.065 \\
\hline$\%$ Conifers vs broad-leafed logs & 105.758 & 31.486 & 0.734 & 16.836 & 37.972 \\
\hline$\%$ Decayed vs. fresh and semi-decayed logs & 2.720 & 0.311 & 3.2003 & 9.201 & 33.022 \\
\hline LW volume $\left(\mathrm{m}^{3} \mathrm{ha}^{-1}\right)$ & 3.149 & 1.863 & 0.064 & 0.081 & 12.232 \\
\hline Single logs volume $\left(\mathrm{m}^{3} \mathrm{ha}^{-1}\right)$ & 1.729 & 0.531 & 0.006 & 0.995 & 2.644 \\
\hline Jammed logs volume $\left(\mathrm{m}^{3} \mathrm{ha}^{-1}\right)$ & 0.841 & 2.014 & 1.569 & 1.761 & 9.767 \\
\hline Number of log jams $\left(\right.$ jams ha $\left.^{-1}\right)$ & 2.969 & 0.539 & 12.213 & 0.355 & 0.359 \\
\hline Number of single logs $\left(\operatorname{logs} \mathrm{ha}^{-1}\right)$ & 0.464 & 3.524 & 2.449 & 2.256 & 0.065 \\
\hline$\%$ Logs floated vs. input from slopes and banks & 17.635 & 15.334 & 16.421 & 8.556 & 14.482 \\
\hline$\%$ logs perpendicular vs. parallel to the flow & 3.554 & 1.779 & 3.681 & 1.972 & 0.143 \\
\hline$\%$ transport/combination vs. autochthonous jams & 0.836 & 2.977 & 0.1224 & 13.333 & 13.938 \\
\hline$\%$ Jams perpendicular vs. parallel to the flow & 0.085 & 1.468 & 5.882 & 0.773 & 0.001 \\
\hline
\end{tabular}
each pair ( $F$ test, numbers in bold are significant at $p<0.05$ )
Table 3. Statistical differences between native forests and pine plantation basins for 


\section{FIGURE CAPTION}

Figure 1. Location of the studied sites (PP and NF refers to pine plantation and native forest basins, respectively).

Figure 2. Average and maximum diameter and length of all logs (either laying alone or jammed) measured within the bankfull channel in the study basins. The boxplots are produced using data acquired on various reaches per studied basin. The solid line indicates the range between the $25^{\text {th }}$ and $75^{\text {th }}$ percentiles, the square icon indicates the median, the whiskers indicate the maximum and minimum non-outlier values, the solid circles indicate outliers, and the diamond indicates extreme value.

Figure 3. Percentage of logs recognised as conifers or broad-leaved species (on the left) and as in a decaying or good state of conservation (on the right) in the study sites.

Figure 4. Volumes of in-channel wood at the studied sites. The graphs show the overall LW volume per ha of channel (a) and the volumes of single (b) and jammed logs (c). The box-plots are produced using data acquired on various reaches per studied basin. The solid line indicates the range between the $25^{\text {th }}$ and $75^{\text {th }}$ percentiles, the square icon indicates the median, the whiskers indicate the maximum and minimum values, the solid circles indicate outliers, and the asterisk indicates extreme value.

Figure 5. Volumes of large wood in mountain basins as a function of the basin area (on the left) and the percentage of native forest cover (on the right).

Figure 6. Number of $\log$ jams and single logs (dimensionalized per ha of bankfull channel) in the studied sites. The box-plots are produced using data acquired at various reaches per studied basin. The solid line indicates the range between the $25^{\text {th }}$ and $75^{\text {th }}$ percentiles, the square icon indicates the median, the whiskers indicate the maximum and minimum non-outlier values, the solid circles indicate outliers, and the asterisk indicates extreme value.

Figure 7. Percentage of logs recognised as having floated from upstream reaches or as being recruited from the slopes or banks within the reach (on the left), and percentage of logs found lying perpendicular or parallel to the flow (on the right).

Figure 8. Percentage of log jams classified as having transport, combination or autochthonous origins (on the left), and percentage of jams found predominantly perpendicular or parallel to the flow (on the right).

Figure 9. Ratio of volumes of sediments trapped by jams and jammed wood in the studied basins.

Figure 10. Comparison of biomass per unit effort between streams in native forests (NF) and pine plantations (PP) (on the left), and the correlations of biomass per unit effort against maximum log diameter and maximum log length (on the right). 


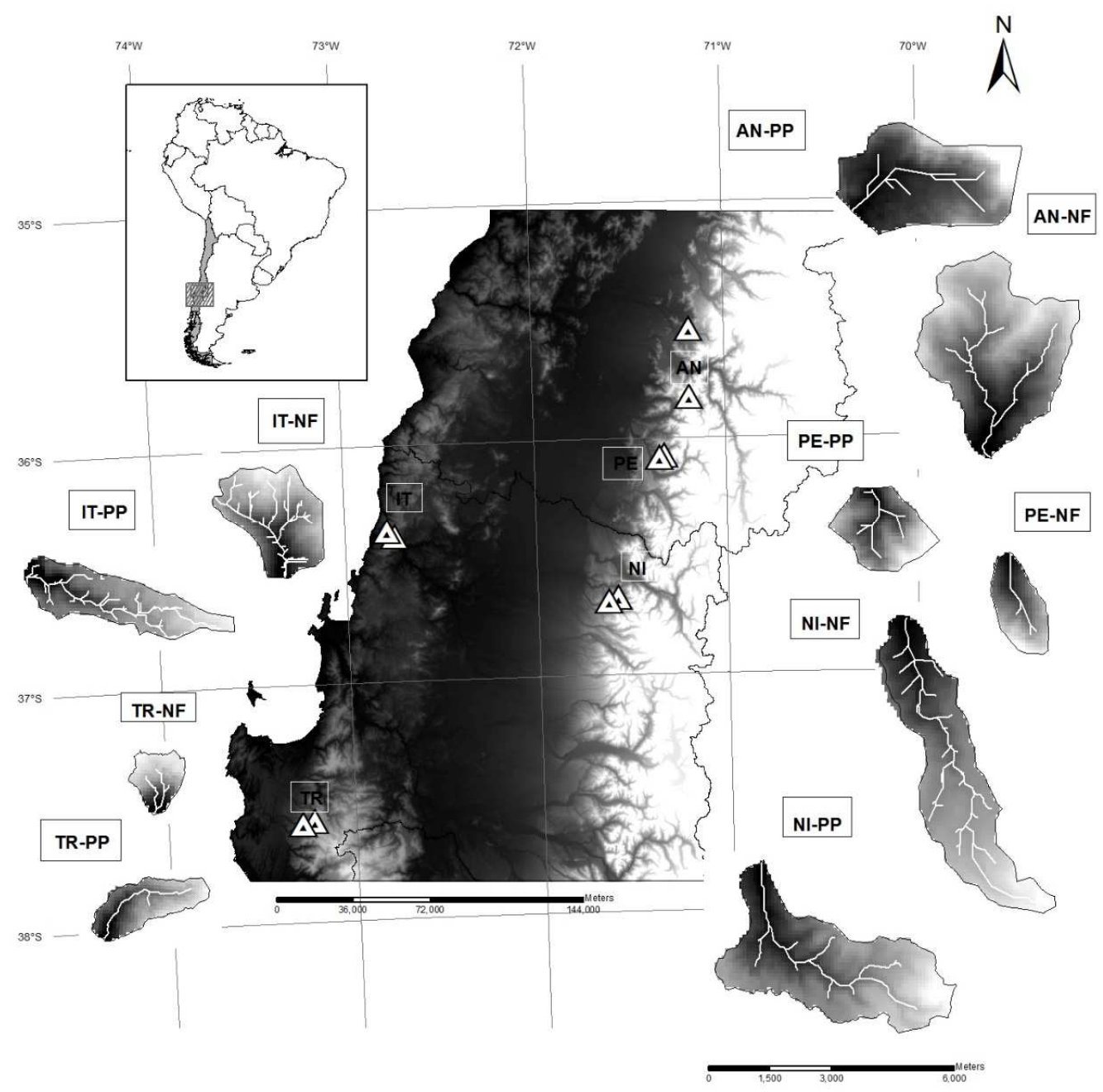




1
2
3
4
5
6
7
8
9
10
11
12
13
14
15
16
17
18
19
20
21
22
23
24
25
26
27
28
29
30
31
32
33
34
35
36
37
38
39
40
41
42
43
44
45
46
47
48
49
50
51
52
53
54
55
56
57
58
59
60
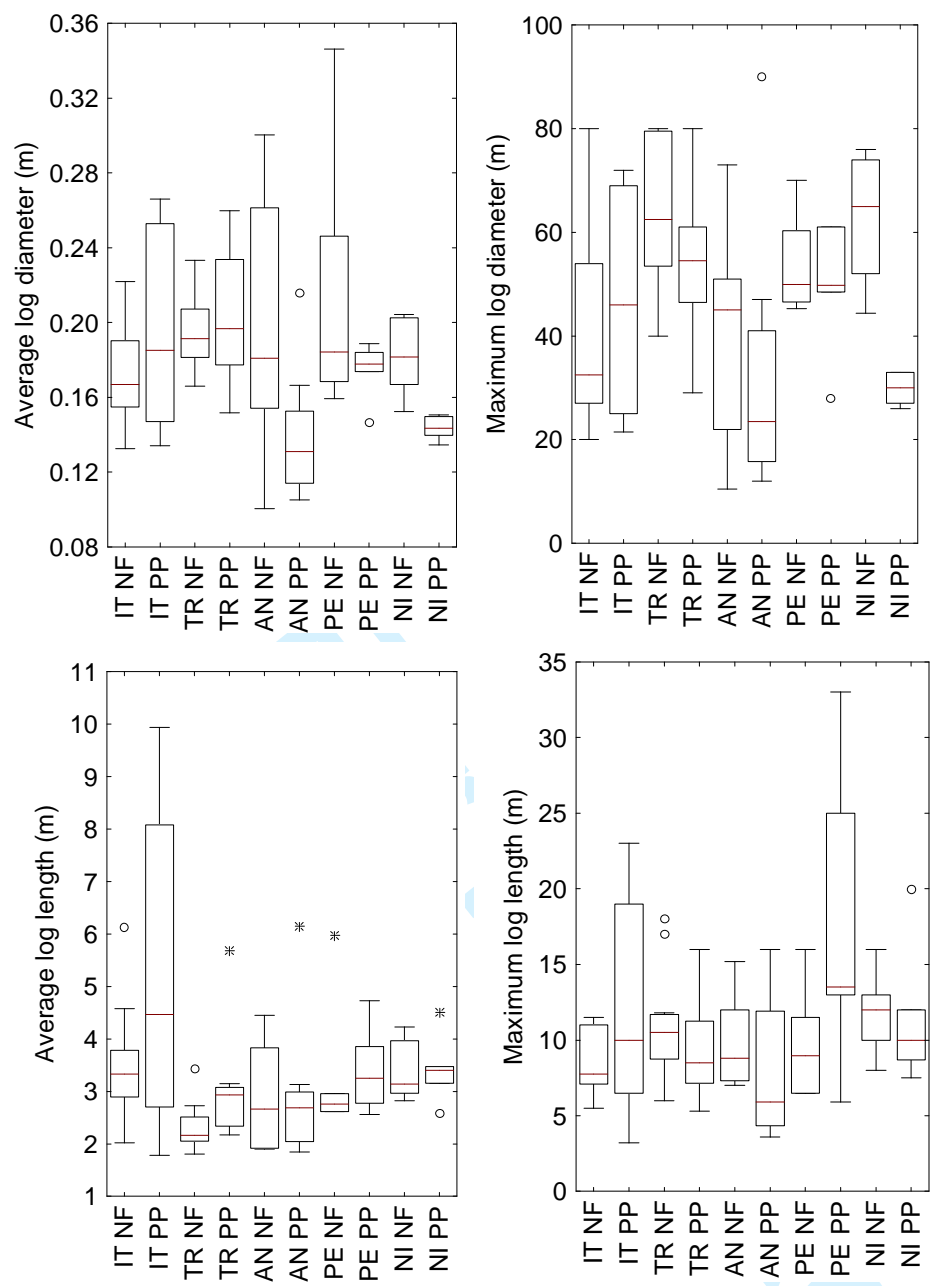

http://mc.manuscriptcentral.com/rra 

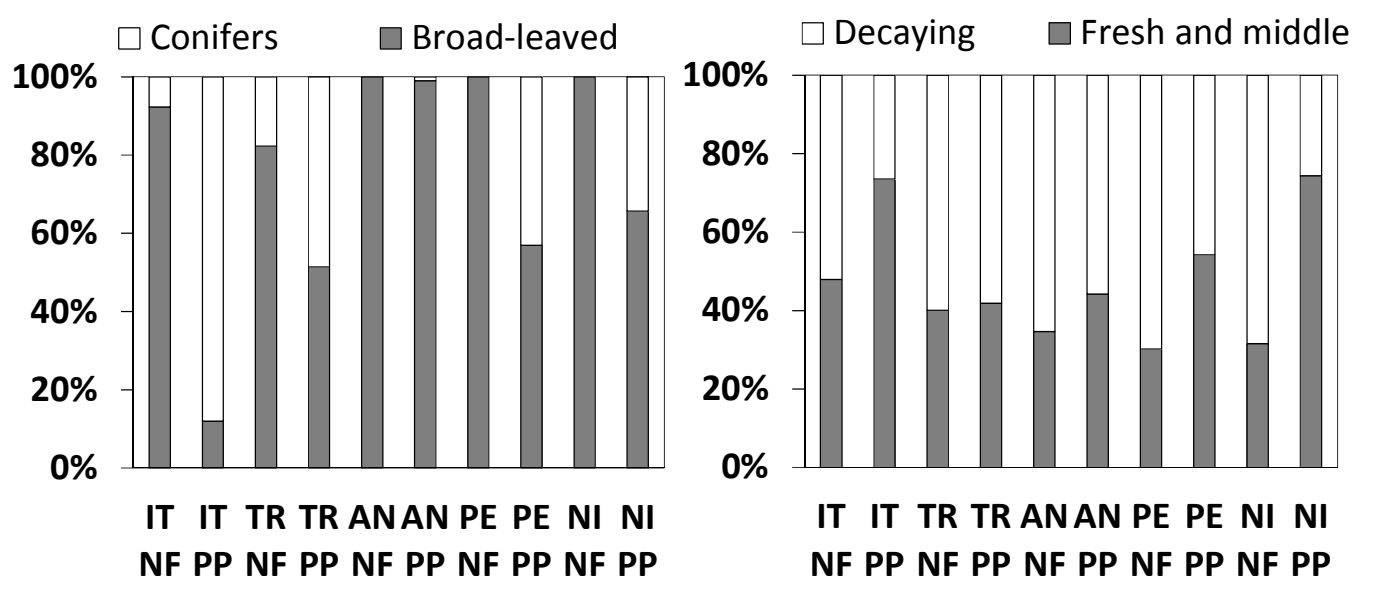


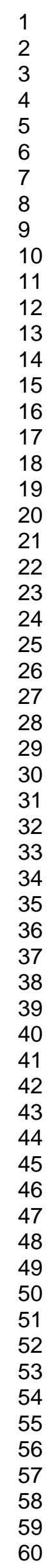
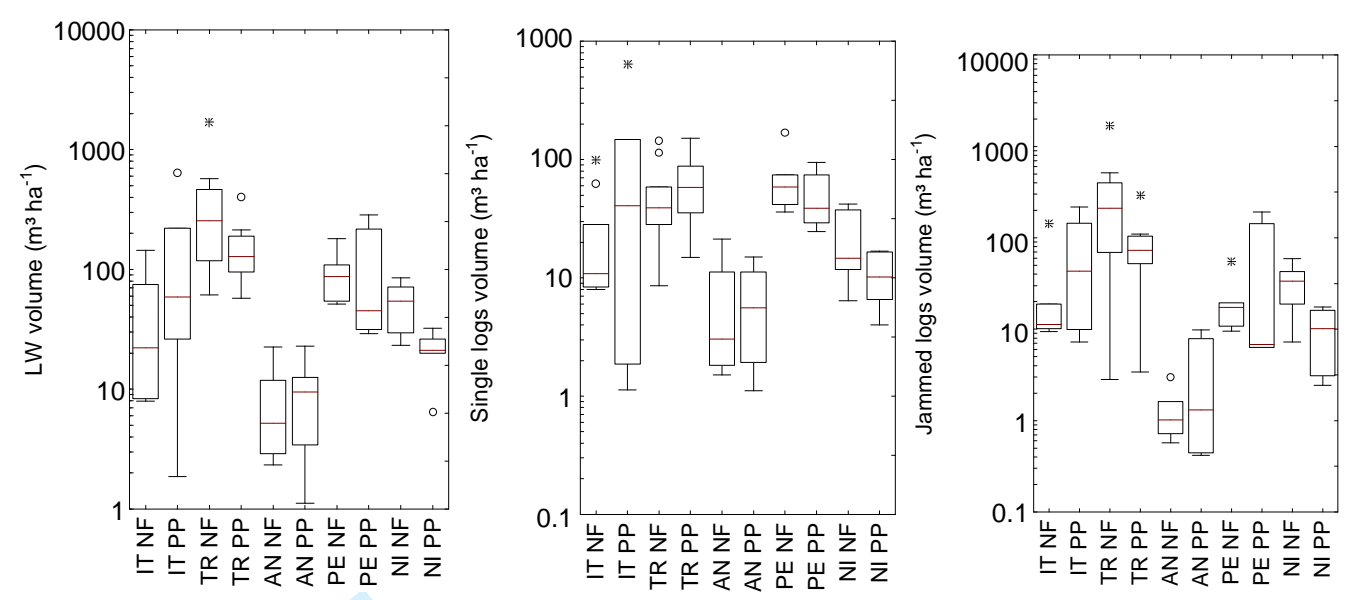

9

0

22

23

24

26

27

29

30

32

33

34

35

36

37

39

40

41

42

44

45

46

47

48

49

50

54

55

56

57

58

60

http://mc.manuscriptcentral.com/rra 

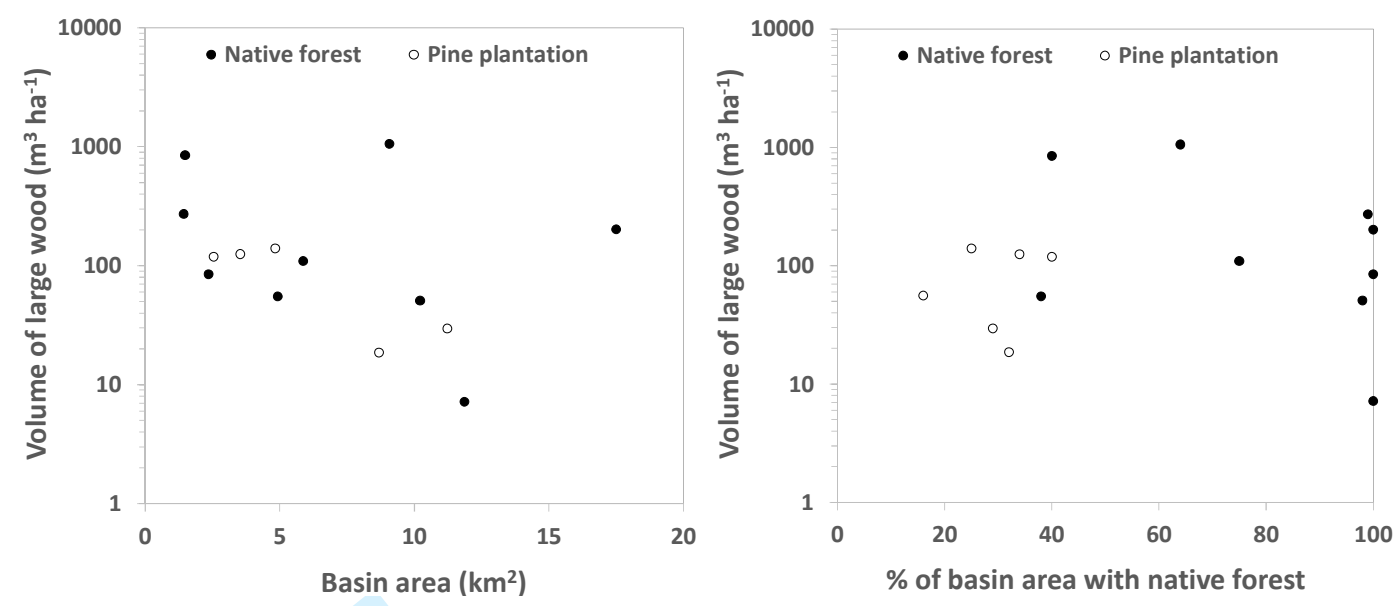

17

18

19

20

21

22

23

24

25

26

27

28

29

30

31

32

33

34

35

36

37

38

39

40

41

42

43

44

45

46

47

48

49

50

51

52

53

54

55

56

57

58

59

60

http://mc.manuscriptcentral.com/rra 


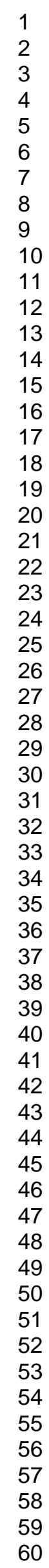
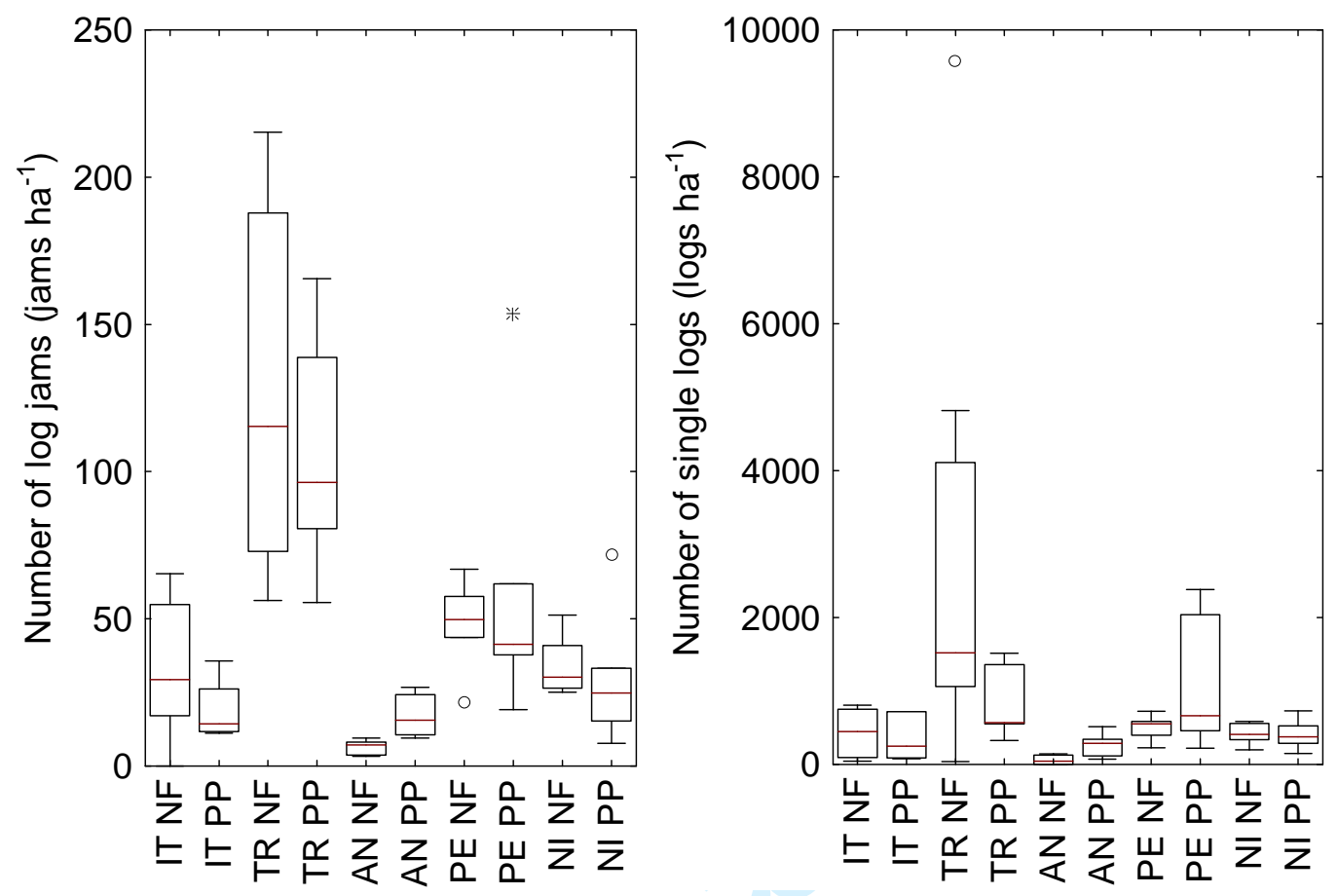

http://mc.manuscriptcentral.com/rra 

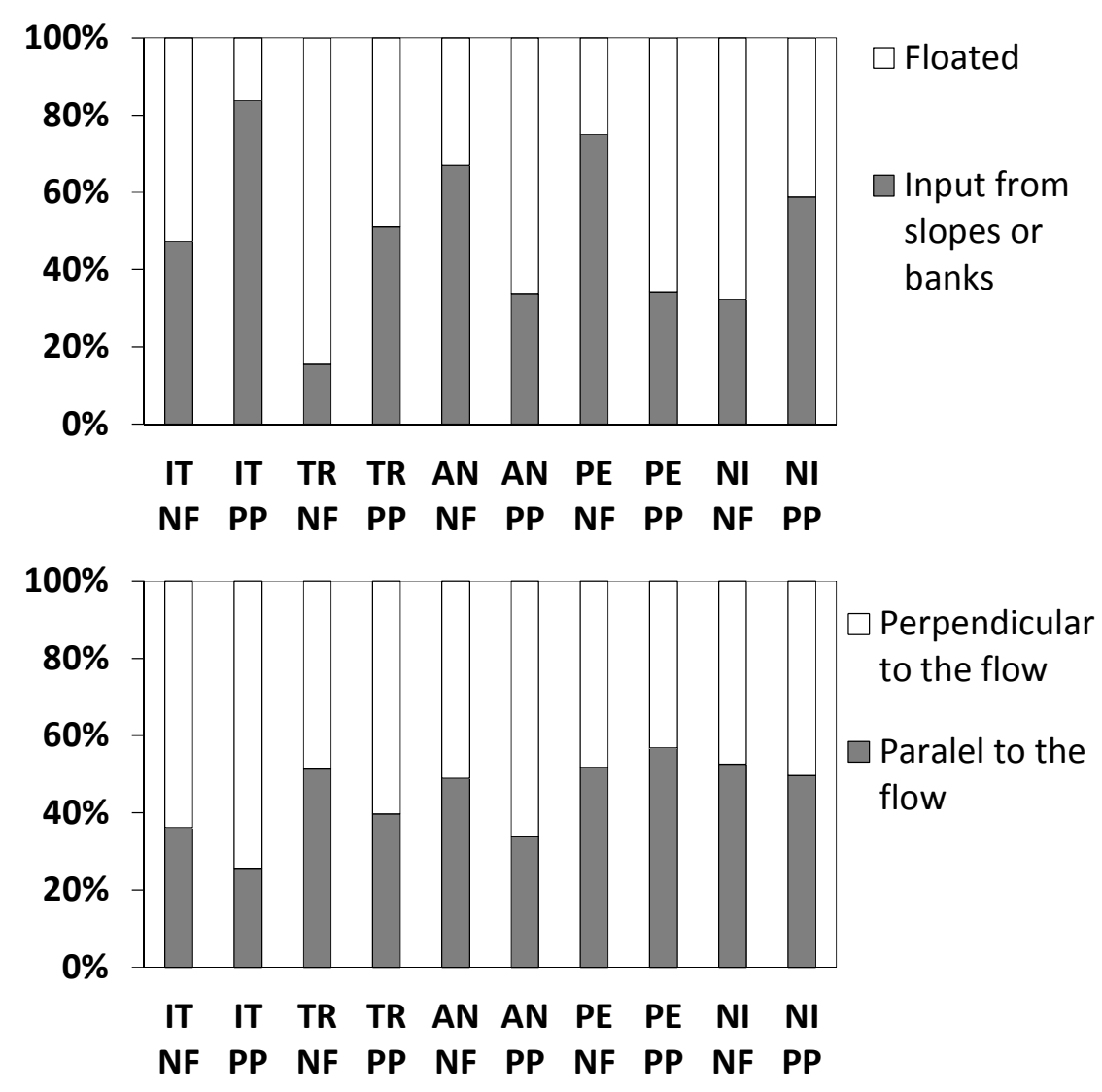

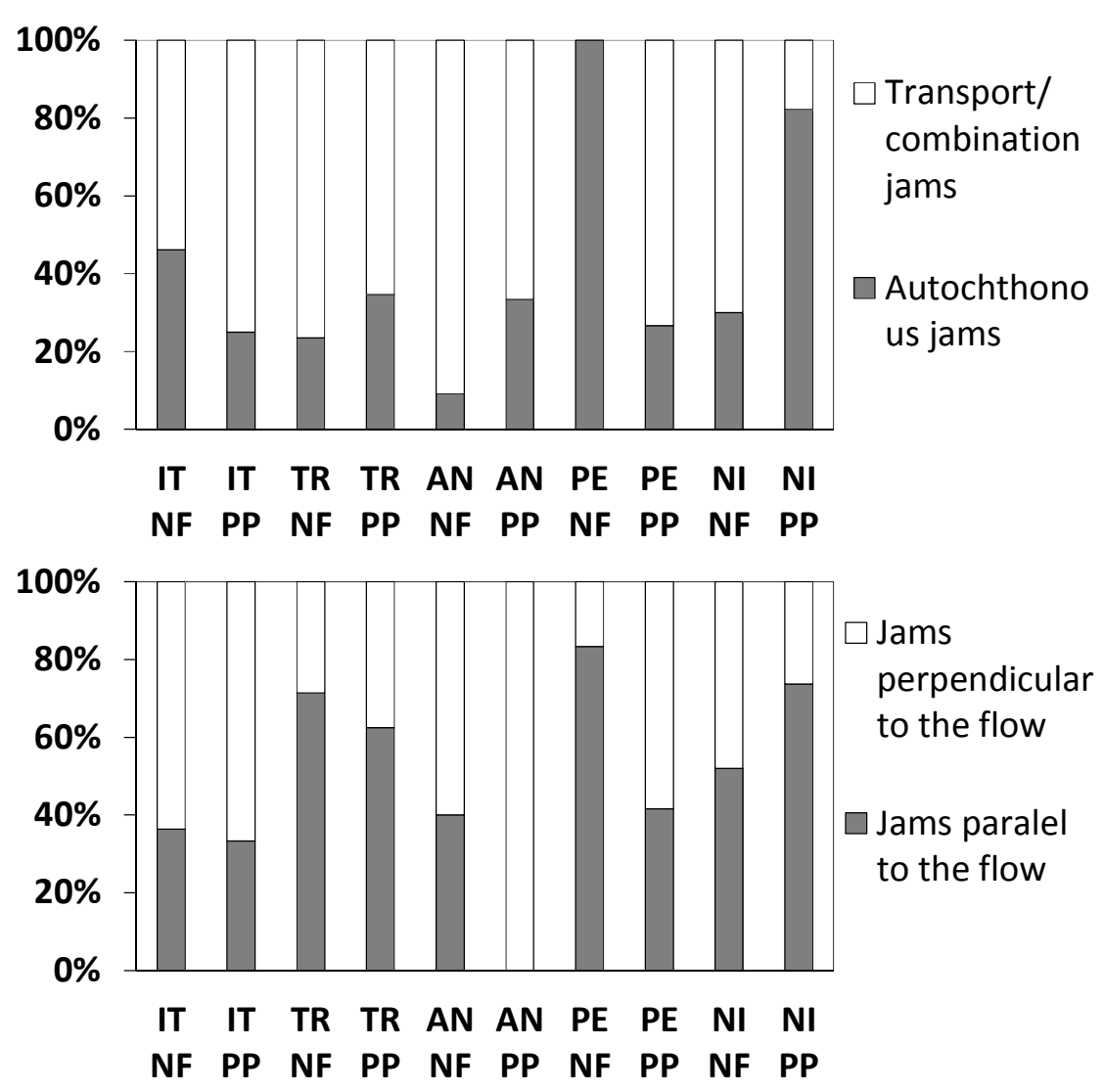


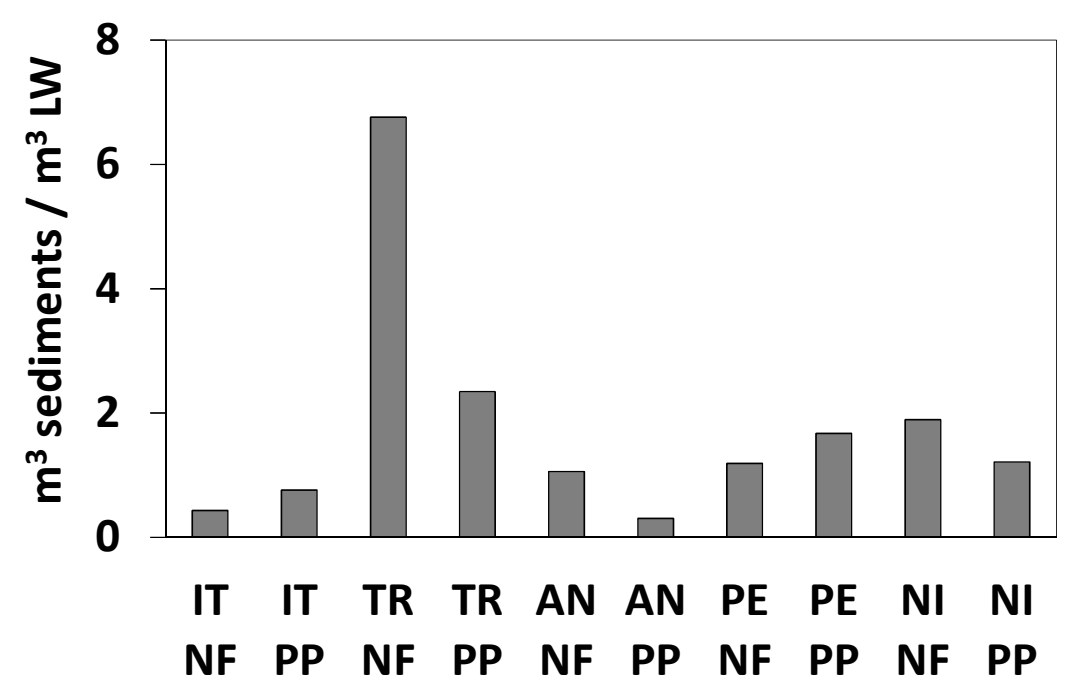

http://mc.manuscriptcentral.com/rra 

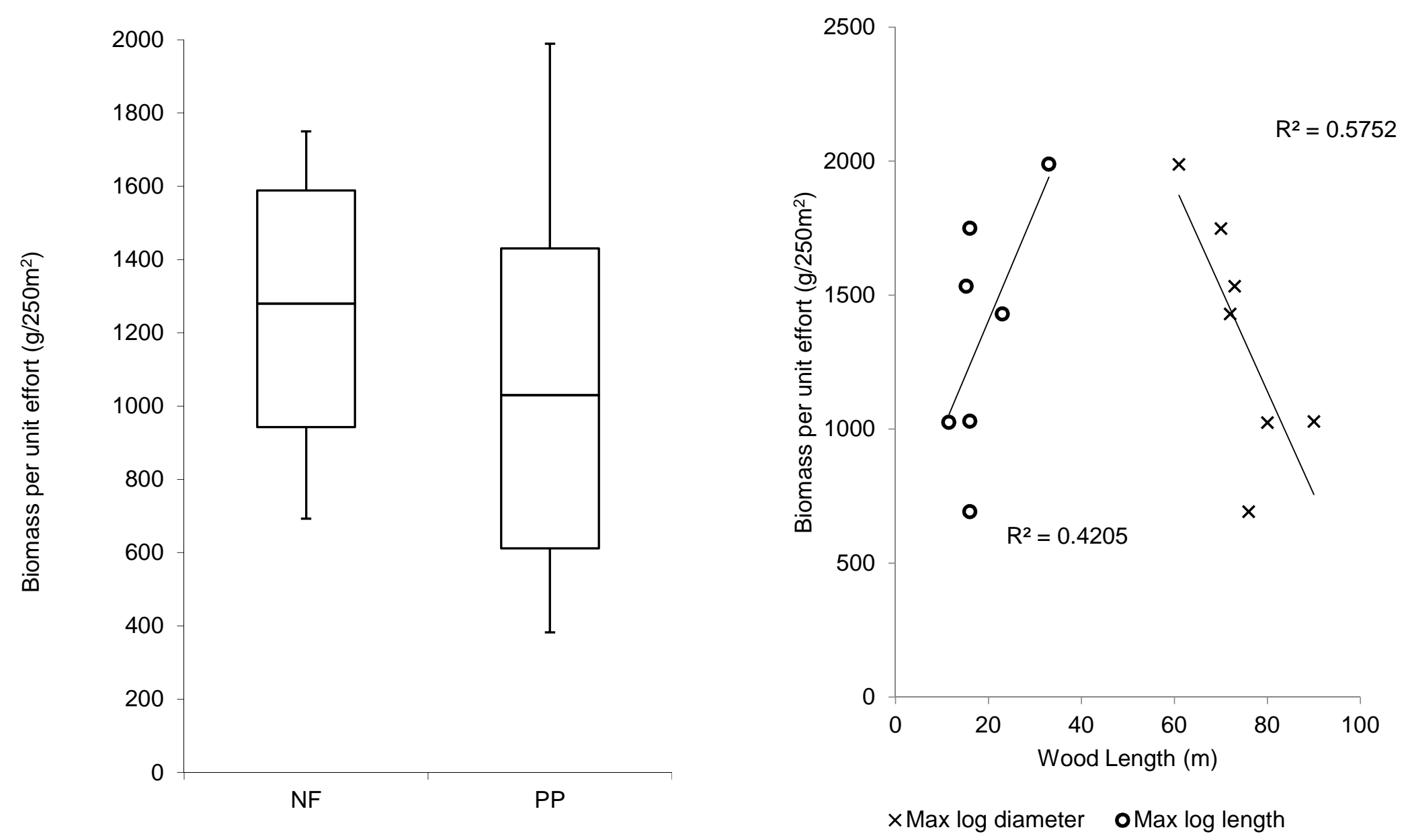